\title{
Biology of the subtropical sac-spawning euphausiid Nyctiphanes simplex in the northwestern seas of Mexico: Interbrood period, gonad development, and lipid content
}

\author{
Jaime Gómez-Gutiérrez ${ }^{\mathrm{a}, *}$, Carmen Rodríguez-Jaramillo ${ }^{\mathrm{b}}$, Jorge Del Ángel-Rodríguez ${ }^{\mathrm{a}, \mathrm{b}}$, \\ Carlos J. Robinson ${ }^{\mathrm{c}}$, Christian Zavala-Hernández a , Samuel Martínez-Gómez ${ }^{\mathrm{a}}$, Nelly Tremblay ${ }^{\mathrm{a}}$ \\ ${ }^{a}$ Centro Interdisciplinario de Ciencias Marinas, Departamento de Plancton y Ecología Marina, Av. IPN, Col. Palo de Santa Rita s/n, La Paz, Baja California Sur 23096, Mexico \\ ${ }^{\mathrm{b}}$ Centro de Investigaciones Biológicas del Noroeste, Mar Bermejo No. 195, Col. Playa Palo de Santa Rita, La Paz, Baja California Sur 23096, Mexico \\ ' Instituto de Ciencias del Mar y Limnología, Universidad Nacional Autónoma de México, Laboratorio de Ecología de Pesquerías, A.P. 70-305, Mexico, D.F. 04510, Mexico
}

\section{A R T I C L E I N F O}

\section{Article history:}

Accepted 30 October 2009

Available online 10 November 2009

Topical issue on "Krill Biology and Ecology." The issue is compiled and guest-edited by the North Pacific Marine Science Organization (PICES), International Council for the Exploration of the Sea (ICES), and Global Ocean Ecosystem Dynamics (GLOBEC) project.

\section{Keywords:}

Nyctiphanes simplex

Sac-spawning

Interbrood period

Histology of gonads

Lipids

Spermatogenesis

\begin{abstract}
A B S T R A C T
Interbrood period, gonad development, and total lipid content throughout the oogenesis and spermatogenesis processes of the subtropical euphausiid Nyctiphanes simplex were studied. Specimens were collected during six oceanographic cruises in Bahía Magdalena (March, July, and December 2004) and in the Gulf of California (November 2005 and January and July 2007). Females attained first spawning when $\sim 7.5 \mathrm{~mm}$ total length ( $>52$ days old). Histological evidence indicates that $N$. simplex females have group-synchronous ovaries, able to produce four broods per gonadic cycle, since ovigerous females develop simultaneously in three and four distinct substages (Oc1, Oc2, Oc3, and Oc4) in their gonads. Once females mature, as shown by pale pink gonads, they may reabsorb their gonads in $<4$ days. Direct observations indicate that after a variable resting period, the formation of oogonia to vitellogenesis takes $\sim 3$ days, investing $\sim 8 \%$ (4-14\%) of weight-specific carbon body weight to reproduction (lipid approach) with an average interbrood period of 10 days (range: 7-26 days, estimated by three distinct methods). About $22 \%$ of the ovigerous females in the metanauplius stage show gonad development in vitellogenesis, likely spawning between 7 and 9 days. The rest of the female population have an interbrood period that is considerably $>10$ days. Embryonic development in the ovigerous sac last $<3$ days $\left(16^{\circ} \mathrm{C}\right.$ ), hatching always as nauplius (usually $100 \%$ hatching success); the metanauplii are released from the ovigerous sac in a median of 5 days after spawning. Although sacspawning euphausiid species may have comparatively lower total fecundity than broadcast-spawning species, they seem to have relatively similar reproductive effort and higher hatching success that increases larval recruitment rates, compared to similar size temperate broadcast-spawners. This partially explains why sac-spawners of the genera Nyctiphanes, Nematoscelis, and Pseudeuphausia are numerically dominant euphausiids in several highly eutrophic temperate, subtropical, and tropical ecosystems. N. simplex males have a continuous spermatogenesis after they attain size at first maturity; continuously allocating $\sim 5.4 \%$ of weight-specific carbon to reproduction, results that are significantly different than previous assumptions that euphausiid male spermatogenesis is energetically insignificant.
\end{abstract}

(c) 2009 Elsevier Ltd. All rights reserved.

\section{Introduction}

Nyctiphanes simplex is a subtropical, sac-spawning euphausiid that dominates, in terms of biomass and abundance, the neritic environment along the northeastern and southeastern Pacific Ocean (Brinton and Townsend, 1980; Brinton et al., 2000). This species, like the other three species of the genus Nyctiphanes, has considerably flexible ontogenetically feeding habits

\footnotetext{
* Corresponding author. Tel.: +52 612123 4666; fax: +52 6121220350 .

E-mail address: jagomezg@ipn.mx (J. Gómez-Gutiérrez).
}

(mostly omnivorous) (Haywood and Burns, 2003; Pilditch and McClatchie, 1994; Ritz et al., 1990), variable early furciliae development pathways (Gómez-Gutiérrez, 1996; Lavaniegos, 1992; LeRoux, 1973; Pillar, 1984), relatively high hatching success (Gómez-Gutiérrez and Robinson, 2005), and a relatively short life span, usually $<1$ year (Lavaniegos, 1992, 1995). These biological features, among others, make these species attain large population densities in the highly dynamic coastal upwelling temperate and subtropical ecosystems.

The assimilation of prey and organic matter that $N$. simplex and other euphausiids ingest are metabolized to increase its biomass 
that is fundamentally directed to three physiological processes: somatic growth, molting, and reproduction. This last involves gonad development and spawning processes (Cuzin-Roudy et al., 1999; Lavaniegos, 1995; Ross and Quetin, 2000; Tarling and Cuzin-Roudy, 2003). Lavaniegos (1995) made the only study that simultaneously estimated these three components of $N$. simplex's secondary productivity. Body growth rate had been most recently estimated for this species (De Silva-Dávila and Palomares-García, 1998; De Silva-Dávila et al., 2002; Gómez-Gutiérrez et al., 1996). Several studies have shown that Nyctiphanes female reproduction accounts for nearly $2 \%$ of total secondary production (Hosie and Ritz, 1983; Lavaniegos, 1995), although now it is known that this proportion of energy is close to 7\% (Gómez-Gutiérrez and Robinson, 2005). This represents almost half of the energy accounted for in broadcast-spawners (Nicol et al., 1995; GómezGutiérrez, 2003a; Gómez-Gutiérrez et al., 2007; Feinberg et al., 2007), which usually invest more than $15 \%$.

Female euphausiids have two distinct spawning strategies: sac-spawners $(\sim 26$ species $)$ and broadcast-spawners $(\sim 60$ species) (Brinton et al., 2000, Gómez-Gutiérrez, 2002, 2003b). Euphausiid reproductive strategies (broadcast vs. sac) have a latitudinal trend in frequency and relative proportion in the euphausiid community structure. Species with broadcastspawning reproductive strategy inhabit virtually all latitudes (from tropical to polar ecosystems) and sac-spawning species tend to inhabit only tropical to temperate ecosystems. Why sacspawning species do not inhabit polar ecosystems is still unknown.

Reproductive biology of broadcast-spawners has been receiving considerably more attention than sac-spawners in all the oceans (Ross and Quetin, 2000). In sac-spawners, reproductive efforts are usually known only from brood size (eggs female ${ }^{-1}$ ) in Stylocheiron carinatum (Ponomareva, 1969), N. difficilis (Nemoto et al., 1972), N. australis (Hosie and Ritz, 1983), N. capensis (Stuart and Nicol, 1986, Barange and Stuart, 1991, Cornew et al., 1992), N. simplex (Gendron, 1992; Lavaniegos, 1995), and Pseudeuphausia latifrons (Wilson et al., 2003). However, the interbrood period (IBP), the time elapsed between two consecutive spawns, has been elusively mentioned in sac-spawners. Egg production (eggs female $^{-1}$ year $^{-1}$ ) of sac-spawners has been estimated only for N. australis (Hosie and Ritz, 1983), N. capensis (Pillar et al., 1992), and $N$. simplex (Lavaniegos, 1995), using preserved ovigerous females; the IBP was estimated indirectly from a histological study of the gonad of a broadcast spawner (Meganyctiphanes norvegica), then conservatively estimated as an average interbrood period of 30 days (Hosie and Ritz, 1983). Gonad development (histological study), lipid content, as well as lipid metabolism, have not been attempted in $N$. simplex and most sac-spawners except $N$. australis (Hosie and Ritz, 1983; Virtue et al., 1995). Therefore, detailed comparison of the oogenesis development of sac-spawners and broadcast-spawners has not been possible so far.

Historically, scientists have assumed that sac-spawners have comparatively lower fecundity and shorter life span than broadcast-spawners because: (1) brood size is limited to the available space in the female ovigerous sac, (2) high energy expense in females from constantly moving their eighth thoracopod to oxygenate the embryos during embryonic development, and (3) inherently, a considerably longer IBP associated with brood care than broadcast-spawners. Consequently, sac-spawners cannot produce and spawn another brood until embryonic development, hatching, and release of the embryos have been completed (Gómez-Gutiérrez and Robinson, 2005). Although the IBP for broadcast-spawners is highly variable because of their capacity to release one egg batch in several spawning events (Cuzin-Roudy and Buchholz, 1999), in temperate euphausiids, its seems to be shorter (average 4-5 days), as in Euphausia pacifica, Thysanoessa inermis, and Euphausia lucens (Feinberg et al., 2007; GómezGutiérrez, 2003a; Pinchuk and Hopcroft, 2006; Ross et al., 1982; Stuart, 1992), than in sac-spawners, such as N. simplex (7-15 days) (Gómez-Gutiérrez and Robinson, 2005).

Female gonad development has also been better studied in temperate and polar broadcast-spawners (Cuzin-Roudy, 1987a, b, 1993, 2000; Cuzin-Roudy and Amsler, 1991; Kikuno and Kawamura, 1983; Ross and Quetin, 1982, 1983, 2000) than in subtropical and tropical broadcast and sac-spawners (Hosie and Ritz, 1983; Stuart and Nicol, 1986; Wilson et al., 2003). For tropical species of both reproductive strategies, studies have usually reported only the number and size of oocytes inside the female carapace from formalin-preserved gonads (Hosie and Ritz, 1983; Mauchline, 1968, 1980; Mauchline and Fisher, 1969; Stuart and Nicol, 1986); hence, no reports of male gonad development are known. As far we know, no published histological studies of gonad development have been made for tropical euphausiids. Lipid content and metabolism have been largely studied in highlatitude species to assess population and specific organs or body fractions of different organs, growth, and maturity stages, particularly in E. superba (Mayzaud et al., 1998) and M. norvegica Cuzin-Roudy et al., 1999). However, there are relatively few estimates of lipid content in subtropical and tropical species. Estimates of total lipid content in each juvenile and adult stage have been reported for $N$. australis (Virtue et al., 1995) and Euphausia lamelligera (Färber-Lorda et al., 2004), but not for each stage of gonad development. To understand the processes of oogenesis and spermatogenesis, we made an analysis of lipid content for all stages of these two reproductive processes. Ultrastructure morphology of euphausiid sperms have been studied only in Euphausia sp. and Meganyctiphanes norvegica (Medina et al., 1998).

In the literature, it is commonly stated that male spermatogenesis is energetically insignificant; however, this process is virtually unknown in most euphausiids (Lavaniegos, 1995; Mauchline and Fisher, 1969; Mauchline, 1980; Nicol et al., 1995). Reproductive rates of males could be relatively high, but they have a shorter reproductive life-span than females, based on recent evidence for the male E. superba that grow fast and die young (Kawaguchi et al., 2007a).

We summarize the reproductive biology and ecology of $N$. simplex as part of a multi-disciplinary effort combining: (1) experimental incubations carried out on board our research vessel to estimate IBP in temperature-controlled experiments and other two indirect methods, (2) female and male gonad histology, and (3) total lipid content at each developmental stage in females and males. We intended to provide an integrated perspective of the reproductive strategies of this subtropical species, hopefully representative of other tropical and subtropical sac-spawners. This information could be the framework to compare sac-spawner's reproductive strategy with the better known reproductive biology and ecology of broadcast-spawners in the oceans.

\section{Methods}

Euphausiids were collected with several planktonic nets on both sides of the Baja California Peninsula during three oceanographic cruises over the continental shelf and in the middle part of the mouth of Bahía Magdalena, Baja California Sur, Mexico $\left(24^{\circ} 30, \mathrm{~N}, 112^{\circ} 30, \mathrm{~W}\right)$ from 16 March to 2 April; 28 June to 16 July, and 1-18 December 2004) and three cruises in the Gulf of California (16 November to 3 December 2005, 12-31 January 2007, and 17 July -3 August 2007) (Gómez-Gutiérrez et al., 2010). 
Table 1

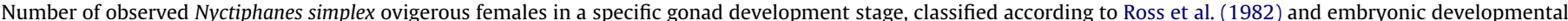
stage from females collected from Bahía Magdalena (March, July, December 2004) and the Gulf of California (November 2005, January and July 2007).

\begin{tabular}{|c|c|c|c|c|c|c|}
\hline \multirow[t]{2}{*}{ Embryonic stage } & \multirow[t]{2}{*}{ EDT hours, (days) } & \multicolumn{4}{|c|}{ Ovigerous female gonad development stage } & \multirow[t]{2}{*}{ Total per row $(\mathrm{n})$} \\
\hline & & Stage I & Stage II & Stage III & Stage IV & \\
\hline Single cells (SC) & $1.8,(0.1)$ & $19(7.5,100)$ & & & & \\
\hline Multiple cells (MC) & $5.5,(0.2)$ & $14(5.5,100)$ & & & & 14 \\
\hline Morula (M) & $\mathrm{a}$ & $7(2.8,100)$ & & & & 7 \\
\hline Blastula (B) & $21.0,(0.9)$ & $39(15.4,95.1)$ & $2(5.6,4.9)$ & & & 41 \\
\hline Gastrula (G) & $39.0,(1.6)$ & $10(4.0,90.9)$ & $1(2.8,9.1)$ & & & 11 \\
\hline Early limb bud (eLB) & $59.5,(2.5)$ & $16(6.3,94.1)$ & $1(2.8,5.9)$ & & & 17 \\
\hline Late limb bud (ILB) & $68.0,(2.8)$ & $10(4.0,100)$ & a & & & 10 \\
\hline Nauplius (N) & $82.0,(3.4)$ & $38(15.0,79.2)$ & $10(27.8,20.8)$ & & & 48 \\
\hline Pseudometanauplius (PMN) & $97.5,(4.1)$ & $24(9.5,70.6)$ & $7(19.4,20.6)$ & $3(10.3,8.8)$ & & 34 \\
\hline Metanauplius (MN) & $116.0,(4.8)$ & $76(30,65.0)$ & $15(41.7,12.8)$ & $26(89.7,22.2)$ & & 117 \\
\hline Total per column (n) & & 253 & 36 & 29 & 0 & 318 \\
\hline
\end{tabular}

Relative abundance (\%) in each column (gonad development stage) and each row (embryonic development stage) is shown in parentheses.

$\mathrm{EDT}=N$. simplex median embryonic development time at $16{ }^{\circ} \mathrm{C}$, expressed in hours and in parenthesis days, according to Gómez-Gutiérrez and Robinson (2005).

a Data not available.

2.1. Collection of live euphausiids, incubation of females to estimate $I B P$, gonad development, and gonad oosorption

Live euphausiid swarms were sampled during the day and at night using a net (1-m wide mouth, $5 \mathrm{~m}$ long, 300- $\mu \mathrm{m}$ mesh), hereafter called live net (Gómez-Gutiérrez et al., 2010). Catches were diluted in 40-L cooler vessels filled with surface seawater from the sampling station. On all cruises, incubation studies were set up in a dark walk-in cold room $\left(16 \pm 0.5^{\circ} \mathrm{C}\right)$ within a few minutes after collection. To set up an incubation experiment, we removed gravid females from the diluted plankton sample and placed each individual in a 1-L bottle filled with filtered $(200 \mu \mathrm{m})$ surface seawater. From 10 to 48 gravid females were incubated per station. Most of the euphausiid incubations lasted $48 \mathrm{~h}$; approximately every $12 \mathrm{~h}$, all bottles were examined. If ovigerous sac females were present or an animal molted, they were usually preserved in $96 \%$ ethanol for later measurement of total length, brood size, and embryo diameter ( $>10$ embryos).

\subsection{Gonad development rates and IBP of females}

We used three methods to estimate rates of gonad development and/or IBP of the sac-spawning $N$. simplex:

(1) Directly observed individual females incubated and monitored every $12 \mathrm{~h}$ under laboratory conditions $\left(16{ }^{\circ} \mathrm{C}, 24\right.$-h dark conditions). Several females were photographed (Olympus Camedia-2030, 3.3 megapixel resolution) every day for up to 15 days, fed a mix of natural phytoplankton and zooplankton sieved with a $20-\mu \mathrm{m}$ mesh net $\left(5 \mathrm{ml} \mathrm{l}^{-1}\right)$, and recorded the time between two gonad development stages and between two consecutive spawns (IBP). We recorded gonad development and, in ovigerous females, embryonic development, as well as further gonad development of monitored females after spawning.

(2) Used the inverse of the proportion of mature females IV (pink gonad) and ovigerous females in groups of 30-300 incubated animals for $48 \mathrm{~h}$ ( $n=29$ oceanographic stations), as proposed by Ross et al. (1982). This method assumes that all females are fertile, there is no population synchronization in the spawning process, and females are homogeneously distributed throughout the sampling area (Ross et al., 1982).

(3) Indirectly estimated the median gonad development rates (stages defined by Ross et al., 1982) based on the median embryonic development rates in the ovigerous sac at constant temperature $\left(16^{\circ} \mathrm{C}, 24\right.$-h darkness). Digital pictures were taken onboard when ovigerous females were identified and measured (while alive) for lipid content and oxidative stress analyses (not part of this study) and from a database of images of ovigerous females at different gonadic and embryonic stages (Table 1; $n=318$ pictures of distinct females). The development time between consecutive gonadic stages was estimated using median embryonic development rates at $16{ }^{\circ} \mathrm{C}$ from justspawned embryos to the time until metanauplii were released (Gómez-Gutiérrez and Robinson, 2005). Gonadic development is highly dependent on exogenous food and temperature, while the rate of embryonic development is highly dependent on temperature (possibly following the Belehradek function), but energetically independent from the environment because embryos have their own yolk that is metabolized until the first feeding stage (Calyotopis 1) (Gómez-Gutiérrez and Robinson, 2005). This method assumed that laboratory feed represented natural food quality and concentration and that the magnitude of overlap between rates of gonadic and embryonic development are small enough to statistically distinguish the median rate for each gonadic stage. The comparison of rates of gonadic and embryonic development provided the relative proportion of females developing into a specific gonadic stage at a known time after spawning defined by the embryonic development rates. This proposed method may be used for other sac-spawners that are difficult to maintain under laboratory conditions.

\subsection{Histology of female and male gonads}

At sea, $N$. simplex were classified by sex and gonadal development according to external morphology (Ross et al., 1982; Table 2), and their total length were measured. For histological observations, groups containing 30 randomly chosen individuals were fixed in Davidson's solution (Howard and Smith, 1983) and placed in plastic cassettes for $48 \mathrm{~h}$ at ambient temperature in the dark. Other female specimens of known gonad developmental stage were preserved in the same way but placed individually in plastic cassettes. After this treatment, all samples were preserved in $70 \%$ ethanol solution for land-based histological analysis. In July 2007, we fixed several specimens in Karnovsky's solution for $48 \mathrm{~h}$ for resin cuts (Karnovsky, 1965).

In the laboratory, all specimens of both sexes were dehydrated with successive series of ethanol concentrations (80, 90, and 100\%) for $1 \mathrm{~h}$ at each concentration. The whole specimens (whole-body 
Table 2

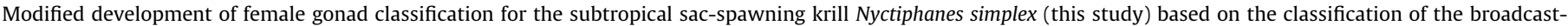

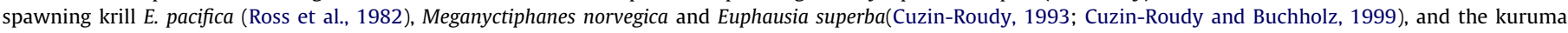
shrimp Penaeus japonicus (Yano, 1988).

\begin{tabular}{|c|c|c|c|c|c|c|}
\hline \multirow{2}{*}{$\begin{array}{l}\text { Gonad stage } \\
\text { N. simplex }\end{array}$} & \multirow[t]{2}{*}{ Oocytes substages } & \multicolumn{2}{|c|}{ Oocytes biometry ( $\mu \mathrm{m})$} & \multirow[b]{2}{*}{ E. pacifica } & \multicolumn{2}{|l|}{ Gonad classification } \\
\hline & & TD & $\mathrm{N} / \mathrm{O}$ & & Panaeus japonicas & $\begin{array}{l}\text { Meganyctiphanes norvegica } \\
\text { and Euphausia superba }\end{array}$ \\
\hline Multiplication & Oogonia (Oc0) & $25.51 \pm 1.40$ & - & I & Oogonia & Oogonia \\
\hline \multirow[t]{2}{*}{ Previtellogenesis } & Early nucleolus chromatin (Oc1) & $42.66 \pm 0.51$ & $2.49 \pm 0.05$ & I & $\begin{array}{l}\text { - Chromatin nucleolus } \\
\text { - Early perinucleolus }\end{array}$ & - Primary oocytes (Oc1) \\
\hline & Late nucleolus chromatin (Oc2) & $85.96 \pm 1.25$ & $0.77 \pm 0.02$ & II & - Late perinucleolus & - \\
\hline \multirow[t]{2}{*}{ Vitellogenesis } & Oil globule (Oc3) & $125.85 \pm 2.70$ & $0.50 \pm 0.03$ & III & $\begin{array}{l}\text { - Primary vitellogenesis } \\
\text { - Oil globule I } \\
\text { - Oil globule II } \\
\text { - Yolkless }\end{array}$ & - Primary oocytes Type 2 (Oc2) \\
\hline & Previtelline globule (Oc4) & $162.83 \pm 3.71$ & $0.34 \pm 0.04$ & III & $\begin{array}{l}\text { - Secondary vitellogenesis } \\
\text { - Yolk granule } \\
\text { - Prematuration }\end{array}$ & - Primary oocytes Type 3 (Oc3) \\
\hline Maturity & Vitelline globule (Oc5) & $232.09 \pm 3.08$ & $0.17 \pm .005$ & IV & - Maturation (ovulation) & - Oocytes Type 4 (Oc4) \\
\hline Spawn & $\begin{array}{l}\text { Germinal vesicle breakdown } \\
\text { (Oc6) }\end{array}$ & $217.66 \pm 17.15$ & - & $\begin{array}{l}\text { Ovigerous } \\
\text { female }\end{array}$ & $\begin{array}{l}\text { - Germinal vesicle } \\
\text { breakdown }\end{array}$ & - \\
\hline Oosorption* & Atretic oocytes (Oc7) & 220.04 & 0.16 & Not defined & - & - Oosorption \\
\hline
\end{tabular}

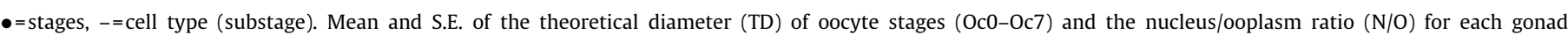

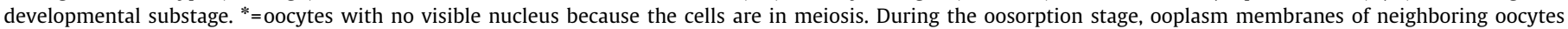
merge.

analysis) was embedded in Paraplast X-Tra at $54-56{ }^{\circ} \mathrm{C}$ fusion point (Davidson) and resin (Karnovsky) (JB-4 Plus, Polysciences,Warrington, PA, USA). The specimens imbedded in Paraplast were cut into $4-\mu \mathrm{m}$ longitudinal and transversal sections of whole specimens (Leica RM 2155 rotatory microtome) and stained for 6 min with Harris's hematoxylin and counterstained for $12 \mathrm{~min}$ with eosinphloxine (Sheenan and Hrapchak, 1973; Humason, 1979). For specimens imbedded in Karnovsky's resin, semi-thin $(1 \mu \mathrm{m})$ sections were cut with tungsten carbide disposable blades (Leica TC65) and stained for 2 min with polychromatic staining (Tolivia et al., 1994). Those sections were used to classify oocyte categories at each developmental stage using criteria of Cuzin-Roudy (1993) and Cuzin-Roudy and Buchholz (1999) for Meganyctiphanes norvegica and Euphausia superba (Table 2). Because ovogenesis is highly conserved in crustaceans (Block et al., 2003) and we detected several gonadal substages in euphausiids that had not been described, we adapted the description of Yano (1988) for gonadal stages in the kuruma shrimp Penaeus japonicus for $N$. simplex. This classification contains more details of oocyte development and reinitialization of meiosis during germinal vesicle breakdown. The oocytes were classified according to the gametogenic developmental stage as: multiplication (Oc0), previtellogenesis (Oc1, Oc2), vitellogenesis (Oc3, Oc4), maturity, (Oc5), spawning (Oc6), and oosorption (Oc7). Stages of oogenesis and their relationship with each kind of oocyte were based on the most developed oocytes found in the ovary (Table 2).

At least two sections of each specimen were analyzed. Slides were examined with an optical microscope (Olympus BX41 with $10 \times, 20 \times$, and $40 \times$ magnification). Images were recorded with a digital image system (Cool SNAP-Pro) and imaging software (Image Pro Plus v. 5.1.0.20). Oocytes in each ovary were classified by stage of development and counted ( $n=20$ oocytes per female) to estimate oocyte area. Because oocytes change in shape as they grow, the formula for the theoretical diameter was used to standardize the diameter data set (Saout et al., 1999):

$T D=\sqrt{\frac{4 A}{\pi}}$

where $T D$ is the theoretical diameter, $A$ is the area of oocytes, and $\pi$ is 3.14159 .

\subsection{Lipid content and fatty acid composition during female and male gonadal development}

Live specimens collected with live, bongo, and/or stratified nets were sorted and observed under an optical stereoscope to identify sex and measure total length. If specimens were female, it was classified by gonadal stage according to Ross et al. (1982). Males were classified as having intruded (MI) or extruded spermatophores (MII). The specimens were rinsed with distilled water and individually placed into sealed cryogenic vials, frozen, transported in liquid nitrogen, and stored at $-80{ }^{\circ} \mathrm{C}$ until analysis. Samples were freeze-dried for $24 \mathrm{~h}$ and dry weight was determined with a microbalance (Cahn C-33). Each freeze-dried specimen was individually homogenized, re-hydrated, and lipids extracted according to Folch et al. (1957). Lipids were determined by the method of Marsh and Weinstein (1966); fatty acids were methyl-esterified under acidic conditions (Christie, 2003). Methyl esters were analyzed by gas chromatography-mass spectrometry. Fatty acids were identified by their mass spectra and comparison with commercial standards. The relative contribution of each fatty acid to the overall fatty acid composition was computed and differences among gonadal stages were compared using ANOVA with arcsine-transformed percentages.

\section{Results}

\subsection{Gonad development rates and IBP of females}

Interbrood period (IBP) was estimated by using three approaches.

(1) Observations of two successive spawns showed that the shortest IBP was seven days for females that spawned and immediately developed the gonad, mostly reaching Stage III (embryos were in the ovigerous sac as a metanauplius phase ready for release from the ovigerous sac $\left(\sim 5\right.$ days at $\left.16{ }^{\circ} \mathrm{C}\right)$ (Fig. 1). Overachieving females usually molted one day after the embryos were released from the ovigerous sac and these females matured again, reaching a pink color in the sixth day 


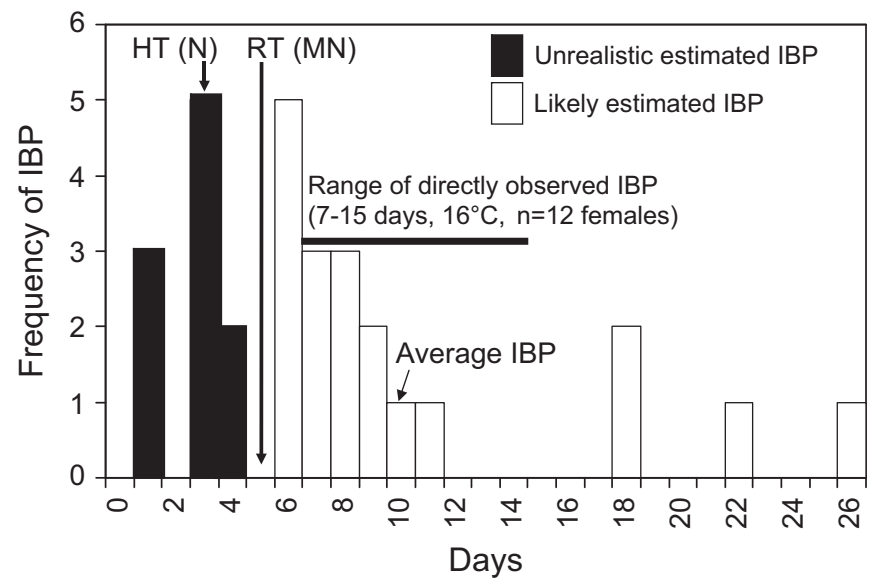

Fig. 1. Comparison of range of observed interbrood period and estimates from the inverse of the proportion of gravid-colored females (Stage IV) collected from the field and incubated under shipboard conditions at $16{ }^{\circ} \mathrm{C}$ (empty bars) of the sacspawning, subtropical euphausiid Nyctiphanes simplex. Black bars are unrealistic values of interbrood period estimated with the method of inverse proportion of gravid females. HT=hatching time, $\mathrm{RT}=$ embryo release time from the ovigerous sac, $N=$ nauplius, $\mathrm{MN}=$ metanauplius.

and spawning seven days after the previous spawn. Most females spawned between eight and 16 days after the previous spawn $(n=9)$. The second spawn under captivity was always infertile, but it was common that females just collected from the field also spawned infertile eggs that dissolve within a few hours, leaving only the ovigerous sac membrane that is later discarded. On one occasion, an ovigerous female discarded her ovigerous sac with the molt. This process is very unusual, probably because it is disadvantageous effects embryos that died several hours later (laboratory conditions).

(2) Using our data from Bahía Magdalena (March, July, December 2004), the inverse of the proportion of mature females (Stage IV) and ovigerous females, in groups of 30-200 randomly selected euphausiids for incubation, we calculated the frequency distribution of the IBP. This method estimated an unrealistically short IBP ( $<4$ days), indicating a non-homogeneous temporal and geographical distribution of ovigerous females at sea. Six days is a likely hypothetical IBP if females are exposed at temperatures $>16{ }^{\circ} \mathrm{C}$, shortening the embryonic development and quickening the rate of gonad development. This method showed a relatively high frequency of the IBP between 6 and 8 days, however there were stations with an estimated IBP as long as 26 days (Fig. 1). Using the IBP data set of 6 to 26 days, the average IBP was 10 days. The seasonal average of the IBP was inversely correlated with temperature, lasting 11.8 days in March (range at a depth of $4 \mathrm{~m}$ was $15.8-18.2^{\circ} \mathrm{C}$ ), 10 days in July (range at a depth of $4 \mathrm{~m}$ was 15.6-20.4 ${ }^{\circ} \mathrm{C}$ ), and 6.6 days in December 2004 (range at depth of $4 \mathrm{~m}$ was $21.3-22.4^{\circ} \mathrm{C}$ ).

(3) We found a consistent association between the relative proportion of ovigerous females, at successive gonadal stages, and the embryonic stages (with known median embryonic development rates) (Table $1, n=318$ females). This provides an estimate of the median development time for euphausiid gonadal stage. For example, all ovigerous females at gonad Stage I would take $<21 \mathrm{~h}$ after spawning because their embryos in their ovigerous sac contained only single cell to morula embryonic stages. We estimated that about $60 \%$ of the ovigerous females developed gonad Stage II between 21 and $82 \mathrm{~h}$ (with blastula and nauplius stage) and the remaining females at $116 \mathrm{~h}$ (with PMN and MN stages). About 90\% of ovigerous females developed gonads to Stage III to MN stage ( $\sim 97$ and $116 \mathrm{~h})$. No ovigerous female was observed at gonadal Stage IV, indicating that a female must take $>5$ days to develop to this gonad stage (Table 1 ). Only $22 \%$ of all ovigerous females analyzed had MN embryo stage and gonadal Stage III at the same time. This indicates that, at least this proportion of females is likely to spawn almost immediately after the embryos are released (IBP $\sim 6-8 \mathrm{~d}$, depending on local temperature and food concentrations). The remaining females are likely to have longer IBPs ( $>9$ days).

\subsection{Histology of female gonad development and observation of female gonad oosorption (atresia)}

This is probably the first study of the gonad of a sac-spawner using histological techniques. Therefore, we describe each gonadal stage and compare gonadal development of better known broadcast-spawners. We propose a six-stage classification of gonadal development in $N$. simplex females, named for a specific characteristic process (Multiplication, Previtellogenesis, Vitellogenesis, Maturity, Spawning, and Oosorption) along with eight oocyte substages (Oc0 through Oc7) (Table 2).

\subsubsection{Stage of multiplication}

The oogonia multiply by mitosis throughout the mature life span of the female. The oogonia grouped in the germinal zones are usually located at the periphery of the gonad (Oc0). Average TD of this cell was $25.51 \mu \mathrm{m}$ (Table 2). Oc0 cells are extremely basophilic, which make them relatively easy to detect by the chromatin inside the nucleus. Oogonia were detected in the undeveloped stage (Fig. 2A).

\subsubsection{Stage of previtellogenesis}

Previtellogenesis includes two oocyte substages: early nucleolus chromatin (Oc1), and late nucleolus chromatin (Oc2). Development of oocytes just after Oc0 had an average TD of $42.66 \mu \mathrm{m}$ (Fig. 2B, Table 2). The nucleus occupies almost all of the ooplasm space with a high nucleus/ooplasm ratio $(\mathrm{N} / \mathrm{O}=2.49)$. Oc1 oocytes were commonly located in the periphery of the ovary near the germinal zones. Oc1 cells had elliptical shape with acutely extreme sides that show strongly basophilic ooplasm; chromatins and several nucleoli appeared dispersed in the nucleoplasm. Oc1 was recorded in all stages after early nucleolus chromatin.

Late nucleolus chromatin (Oc2) oocytes had a mean TD of $85.96 \mu \mathrm{m}$ (Fig. $2 \mathrm{C}$, Table 2). Oc2 oocytes were significantly larger than Oc1 cells and the N/O ratio decreased to 0.69-0.77. Oc2 oocytes were located throughout the ovary, but usually close to Oc1 clusters. Numerous follicular cells were strongly basophilic and frequently observed surrounding Oc2 oocytes. The shape of the oocytes was irregular and the ooplasm was slightly basophilic. The nucleus was large, round; several flat and very small nucleoli were in the periphery of the nuclear membrane (Fig. 2C).

\subsubsection{Stage of vitellogenesis}

Vitellogenesis is characterized by rapid growth of the oocytes. At the oil globule substage (Oc3), oocytes had a mean TD of $125.85 \mu \mathrm{m}$ and the $\mathrm{N} / \mathrm{O}$ ratio was 0.50 , increasing the ooplasm area in relation to the nucleus (Fig. 2D, Table 2). Oc3 oocytes had a polygonal shape and numerous acidophilic oil globules dispersed within the ooplasm precursor of the yolk. The cells of the follicle layer are now smaller and less abundant (Fig. 2D). This cell type was included in the vitellogenesis stage, but considered as an oil 
(A)

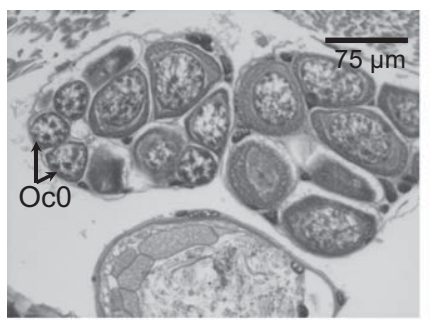

(B)

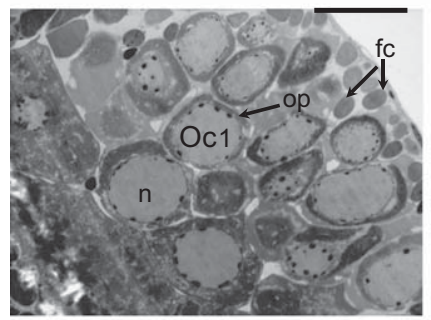

(C)

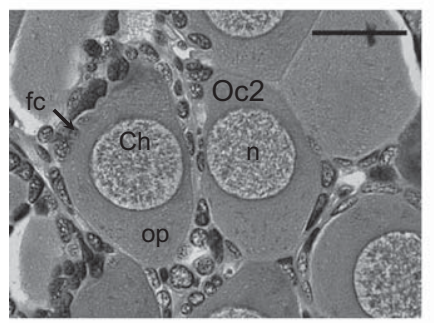

(D)

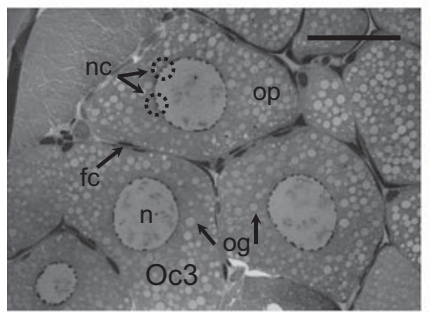

(E)

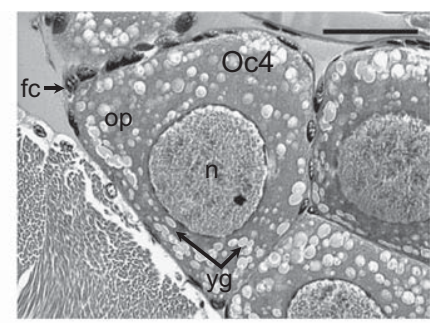

(F)

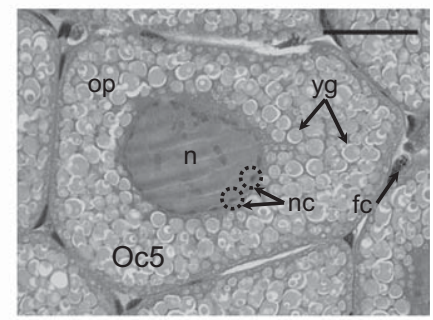

(G)

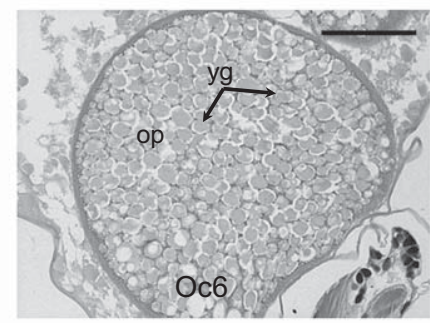

(H)

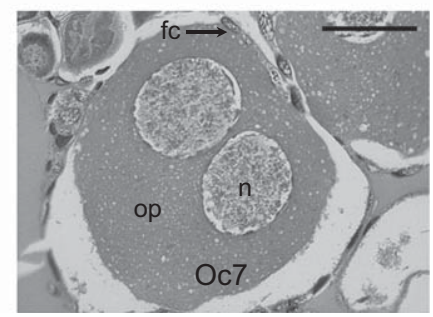

Fig. 2. Female gonadal development (oogenesis) of Nyctiphanes simplex using hematoxilin-eosin stain (magnification $200 \times$, scale bars $=75 \mu \mathrm{m}$ ). (A) Ovary in multiplying stage with oogonia (Oc0); (B-D) Ovary in Stage I (previtellogenesis) with (B) oocytes in early chromatin nucleolus substage (Oc1); (C) oocytes in late chromatin nucleolus substage (Oc2), $\mathrm{Ch}=$ Chromatin; (D) Oocytes in oil globule substage (Oc3) (endogenous phase of vitellogenesis); (E) Ovary in Stage II (exogenous phase of vitellogenesis) with oocytes in previtelline globule substage (Oc4); (F) Ovary in Stage III (mature) with oocytes in vitelline globule substage (Oc5); (G) Ovary in Stage IV (spawning) with oocytes in germinal vesicle breakdown substage (OC6); (H) Ovary in Stage V (oosorption) with atretic oocytes substage (Oc7). $\mathrm{fc}=$ follicular cells; op=ooplasm; og=oil globule; $\mathrm{yg}=$ yolk granule; $n=$ nucleus; $\mathrm{nc}=$ nucleolus; $\mathrm{Hep}=$ hepatopancreas; TA=terminal ampoule.

globule rather than a lipid droplet because the morphological structure of the oil globule in $N$. simplex is very small and presumably a precursor of yolk rather than lipids.

At the pre-yolk substage (Oc4), the mean TD of oocytes was $162.83 \mu \mathrm{m}$ and the mean N/O ratio was 0.34 (Fig. 2E, Table 2). In the basophilic ooplasm, there are several strongly acidophilic droplets of different sizes. The cells of the follicle layer were very thin (Fig. 2E).

\subsubsection{Stage of maturity}

At the yolk granule stage (Oc5), the average TD of oocytes was $232.09 \mu \mathrm{m}$ with an average $\mathrm{N} / \mathrm{O}$ ratio of 0.17 (Fig. 2F, Table 2).
Yolk granules reached their maximum size and the oocytes were completely full of acidophilic yolk granules (Fig. 2F).

\subsubsection{Stage of spawning}

Germinal vesicle breakdown (Oc6) occurs; average TD of the oocytes was $217.66 \mu \mathrm{m}$ (Fig. 2G, Table 2). At this stage, it was not possible to measure the $\mathrm{N} / \mathrm{O}$ ratio because the cells restart meiosis and germinal vesicle breakdown. Yolk granules, immersed in the oocytes, were less dense than at Oc5 (Fig. 2G). Follicular cells disappear from around the oocytes, which indicates that the oocytes were released (Fig. 2G).

\subsubsection{Stage of oosorption}

Atretic oocytes are re-absorbed (Oc7); average TD was $220.04 \mu \mathrm{m}$ and the $\mathrm{N} / \mathrm{O}$ ratio was highly variable, ranging between 0.05 and 0.16 (Fig. 2, H, Table 2). The Oc7 cells are no longer able to have a reproductive function because absorption of the ooplasm membranes leads to fusing with neighboring cells. Oc7 oocytes were completely irregular in shape, independent of the oocytes stage (Oc1-Oc5). Oc7 oocytes progressively decreased in size until complete oosorption by phagocytosis (Fig. $2 \mathrm{H}$ ).

Observations of gonad development are based on nine females. The sequence of pictures shown here were from a female reared for 15 consecutive days (Figs. 3A-O) after Oc6. It demonstrated that, at the start of the mature stage (pink gonad) females can reabsorb (oosorption process) their gonad in as few as 4 days (Figs. 3A-D). Cell walls started to dissolve at the beginning of the oosorption process; histological sections showed two or three cells fused with two nucleuses throughout the gonad (Fig. 3B). At late oosorption, several cells were fused, several areas with a nucleus and others apparently without a nucleus (Fig. 3D). The resting phase was highly variable, which is characterized as an apparently empty space in the cephalothorax. However, histological evidence shows that gonads always have germinal cells during the gonad-resting period. This process usually took three to seven days, but could be longer (Fig. 3E-K). The length of the resting phase may depend on the quality and quantity of food, stress, temperature. Gonad development from early oocytes to previtellogenesis and vitellogenesis was also fast, occurring in at most four days (Fig. 3L-O).

\subsection{Relative proportion of oocytes types (Oc1-Oc7) in the stages of gonadal development}

According to Wallace and Selman (1981), N. simplex has groupsynchronous ovaries, since at each stage of gonad development, three or four oocyte substages are present (Fig. 4A). Oc1 oocytes are observed throughout gonadal development, indicating continuous production of germinal cells for continuous reproduction throughout adult life span. During previtellogenesis, Oc1 cells were considerably more abundant than Oc2; during vitellogenesis, Oc3 and Oc4 appeared, but the Oc3 cells were more than twice as frequent as all other oocyte substages. At the mature stage, Oc5 cells appeared and remained in the gonad until the spawning stage, when Oc6 appeared with breakdown of the germinal vesicle. During the oosorption process, all cell types diminished until only Oc1 cells remained (Fig. 4A). The gametogenic cycle of sacspawners included six stages where the female returns from the spawning stage to exogenous secondary vitellogenesis periodically, maturating perhaps 3 or 4 partial spawning events per ovarian cycle. It is common for ovigerous females to have two types of oocytes during previtellogenesis (Fig. 4B-C) and three types of oocytes simultaneously (Oc1, Oc2, Oc3, or Oc4) during vitellogenesis (Figs. 4D-E). It is unlikely that these four spawning events occur between only in one intermolt period because we 


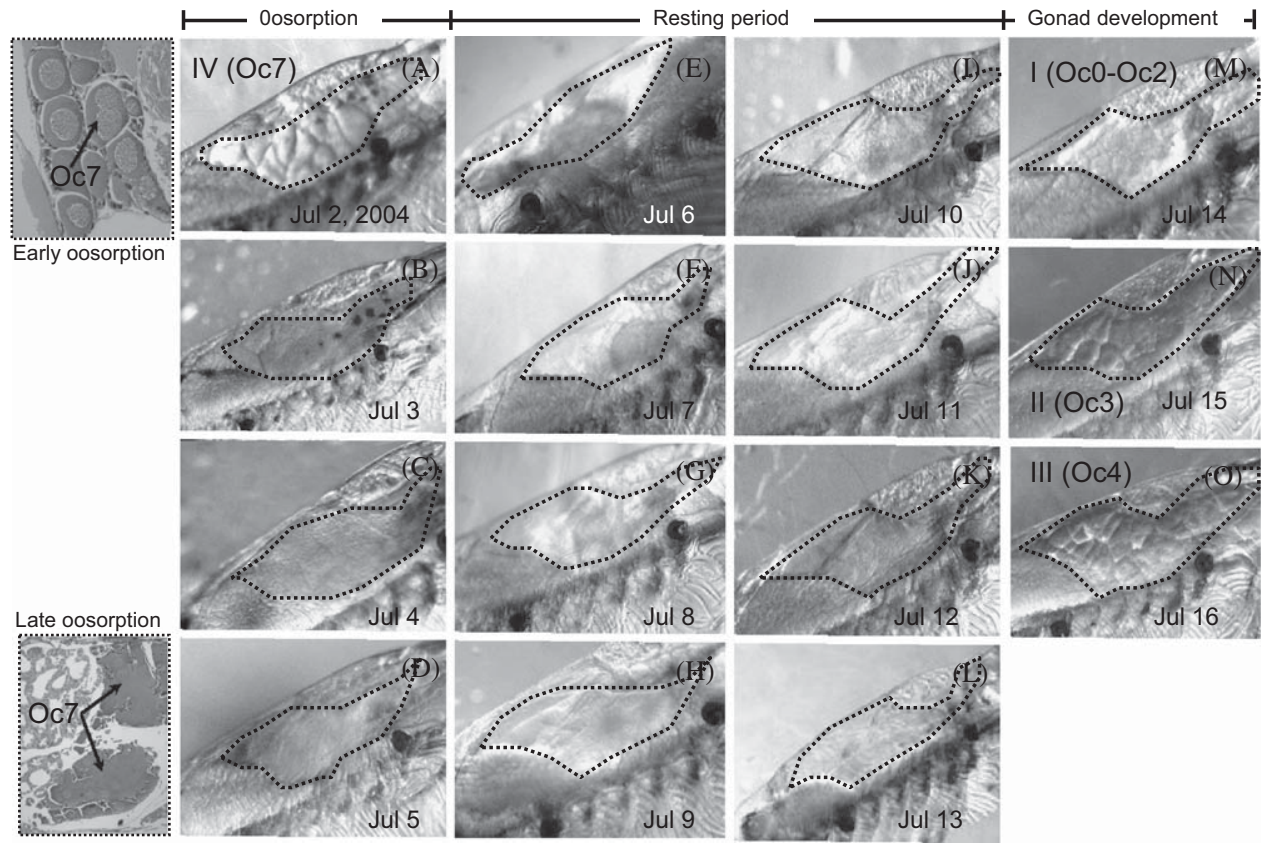

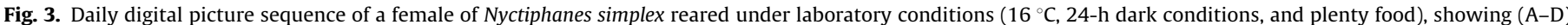

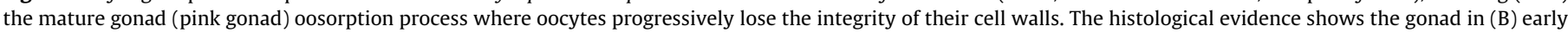

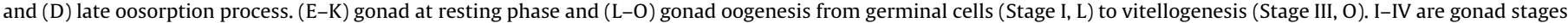
according Ross et al. (1982). Oc0-Oc7 oocytes were used for classification in this study. Dashed line=delimited gonad area.

frequently observed females molting one day after they released their embryos and spawning again one or two days later. Gonads of ovigerous females with metanauplius embryos may be at the vitellogenesis stage. Histological evidence shows that Oc1-Oc3 oocytes are frequently present at this stage of embryonic development (Figs. 4D-E).

\subsection{Histology of male gonads during development}

The male reproductive system includes a pair of testes located beneath and bordering the pericardium and heart, extending down to the first abdominal segment (posterior part of the gonad), a pair of vas deferens, a terminal ampoule, and the material presumed to be a spermatophore layer where the spermatozoa accumulate and can be transferred to the female during mating (Fig. 5A). N. simplex spermatogenesis includes five cell types: spermatogonia (Spg, Fig. 5B), primary spermatocytes (Spc1, Fig. 5C), secondary spermatocytes (Spc2, Fig. 5D), spermatids (Spm, Fig. 5E), and spermatozoa (Spz, Fig. 5F). Development in the testicular cords progresses from the anterior (clusters of young spermatogonia) to the posterior part of the testicle (clusters of old cells, spermatozoa), each with a distinct and homogeneous cell type. A germinal cells layer, similar in appearance to spermatogonia is typically localized on the periphery of the cord. All cell development types can be observed in a single longitudinal histological section, indicating that $N$. simplex spermatogenesis is continuous.

Cellular differentiation consists of spermatogonia, containing a large granular nucleus with sparse cytoplasm (Fig. 5B), that transform into primary (Fig. 5C) and secondary spermatocytes (Fig. 5D). Synchrony in cellular division is typical (note the mitotic features in Fig. 5C, D). Each secondary spermatocyte divides into four spermatid cells with acidophilic nuclei that are relatively homogeneous (Fig. 5E). The spermatozoa have a triangular shape and are mostly basophilic, immersed into an acidophilic acellular spermatophore. The sperm are non-motile cells (non-flagellated) (Fig. 5F). This brief description represents only the development of functional cells, not nurse cells, nutrition and accessory cells, or associated structures.

\subsection{Lipid content during stages of gonadal development of females}

Analysis of lipid content of females was restricted to immature females (gonad development Stages I to III) and mature females that are ready to spawn (pink gonad Stage IV), using the description of Ross et al. (1982). Lipid content of $N$. simplex females had a linear relationship at all gonad development stages as a function of the euphausiid's total length, which explained $\sim 63 \%$ of its variability (Fig. 6 A). Although lipid content per stage did not show abrupt changes at female gonad stage III (Fig. 6B), we observed that as females progress through the gonadic cycle, the largest increase between successive gonad stages occurred between Stage II and Stage III (Fig. 6B). Lipid content of females at Stages III and IV was 1.2-2.2 times greater than lipid content of females at Stages I and II of similar length (Fig. 6A). This is consistent with the occurrence of vitellogenesis at Stage III. Accordingly, only females at Stages I and II should be categorized as in the previtellogenesis (Table 2). Our results show that a female at previtellogenesis can increase its mean lipid content from 120 to $270 \mu \mathrm{g}$ ind $^{-1}$ during vitellogenesis.

\subsection{Lipid content during gonad development of males}

Analysis of lipid content of males was restricted to mature males with intruded spermatophores (MI) and mature males with extruded spermatophores (MII) that are ready to mate. Lipid content of MI and MII did not show a significant relationship with total length $(P>0.05)$ (Fig. 6D), but MII had significantly more lipid $\left(366 \mu \mathrm{g}\right.$ ind $\left.^{-1}\right)$ than MI $\left(191 \mu \mathrm{g} \mathrm{ind}^{-1}\right)$, which was independent of total length (Fig. 6C), an average increase of $175 \mu \mathrm{g}$ ind $^{-1}$. 


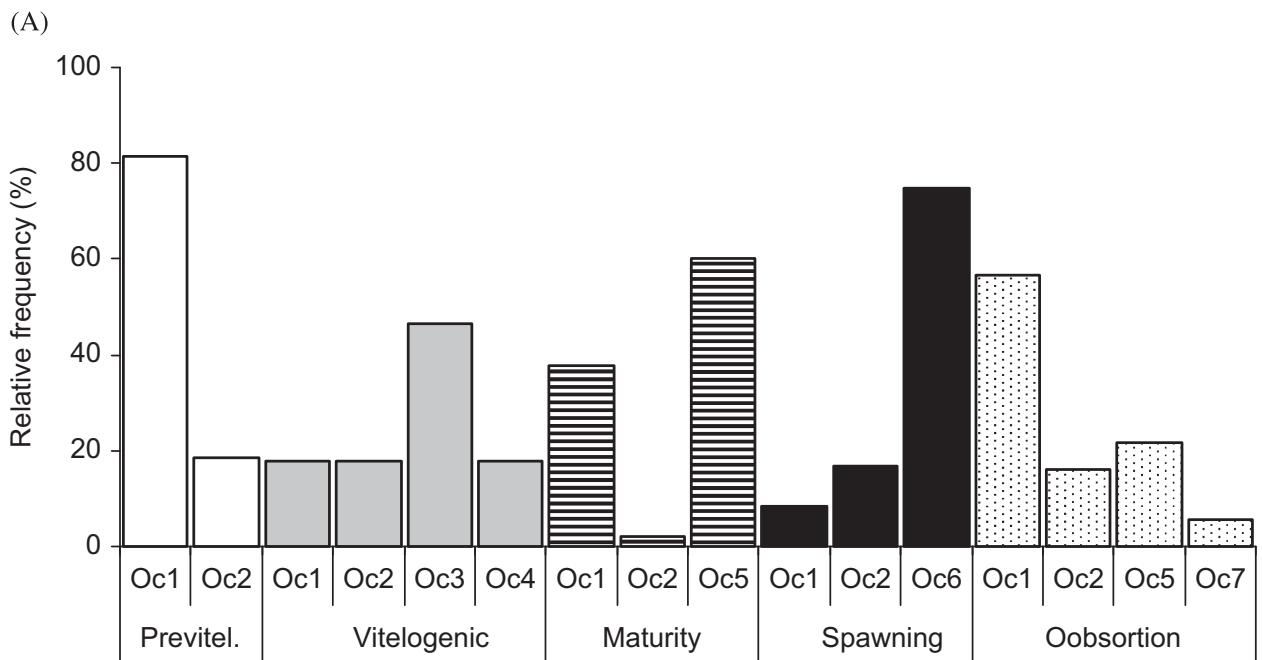

(B)

(D)
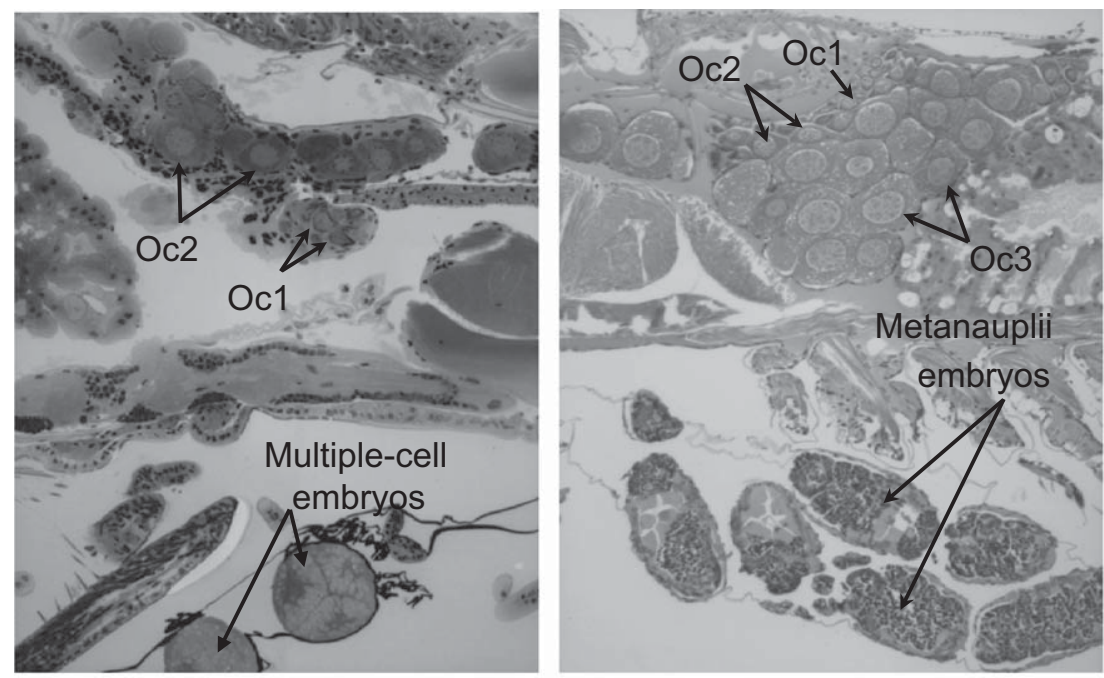

(C)

(E)
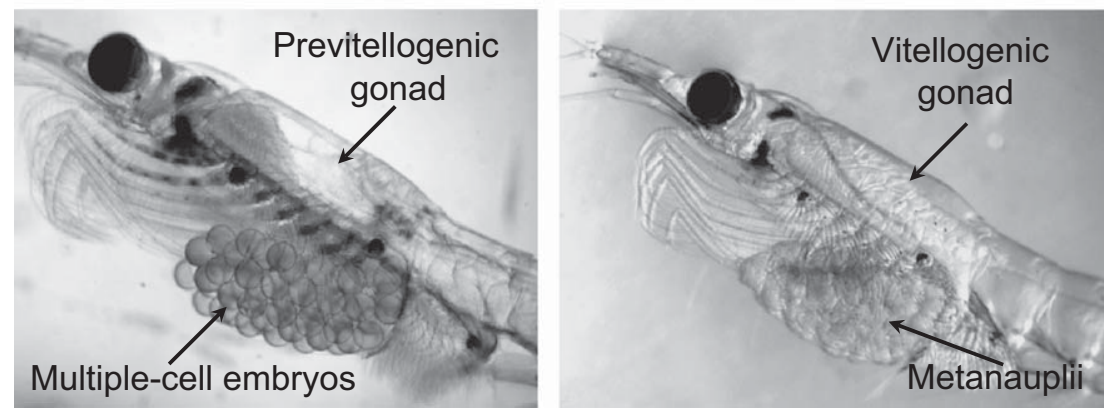

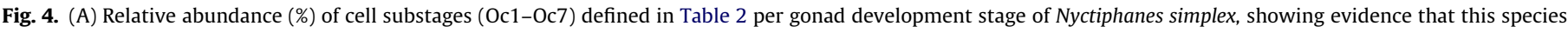

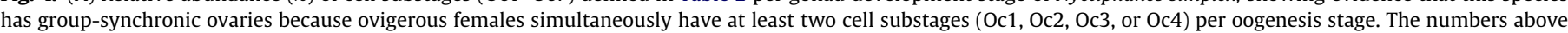

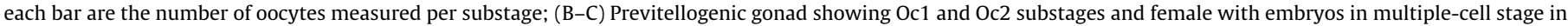

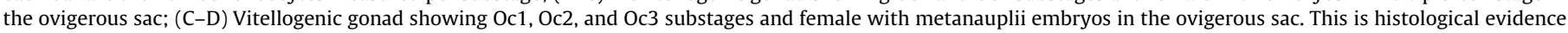
that an ovigerous female can produce up to four ovigerous sacs per gonad cycle.

\section{Discussion}

\subsection{Interbrood period and egg production}

Reproduction in tropical and subtropical broadcast-spawners has been far less studied than temperate, subpolar, and polar broadcast-spawners. This is also true for reproduction in sacspawners. In general, such studies have been largely done with preserved animals, therefore reproduction rates (interbrood
period=IBP) have not been directly measured; but assumed or indirectly estimated (Barange and Stuart, 1991; Hosie and Ritz, 1983; Lavaniegos, 1995; Nemoto et al., 1972; Ritz and Hosie, 1982; Wilson et al., 2003). Tropical euphausiids have relatively high vital rates modulated by relatively high temperatures. For example, we observed Euphausia distinguenda hatch in $<18 \mathrm{~h}$ at $22{ }^{\circ} \mathrm{C}$ (Gómez-Gutiérrez, unpubl. results), which is considerably shorter than temperate broadcast-spawners like E. pacifica and T. spinifera (27-50 h at $10^{\circ} \mathrm{C}$ ) (Gómez-Gutiérrez, 2002). However, 
(A)

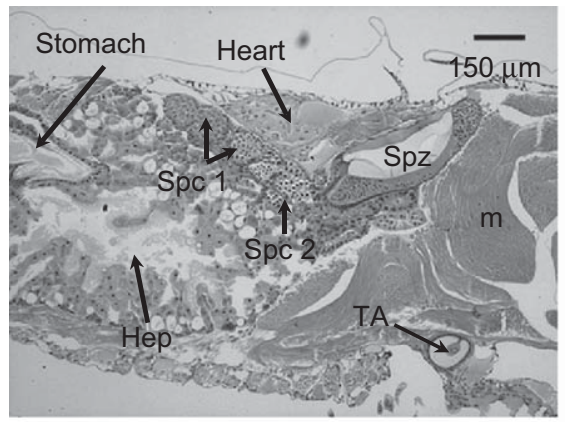

(B)

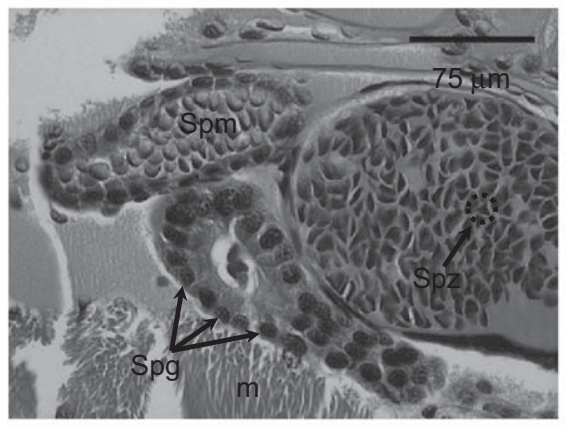

(C)

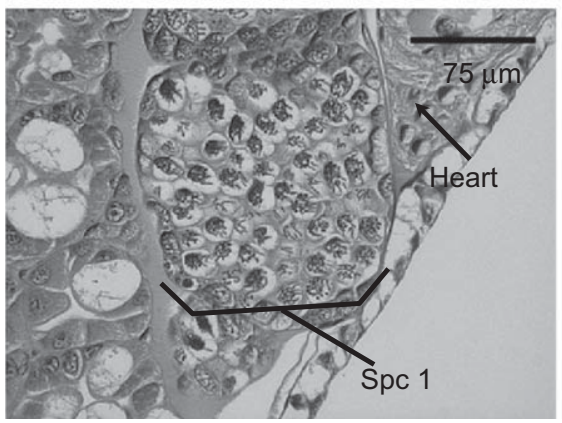

(D)

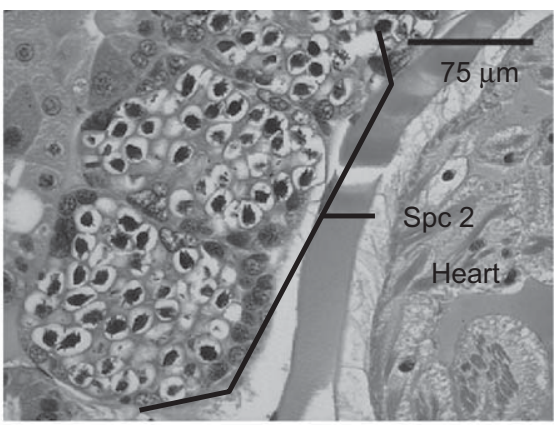

(E)

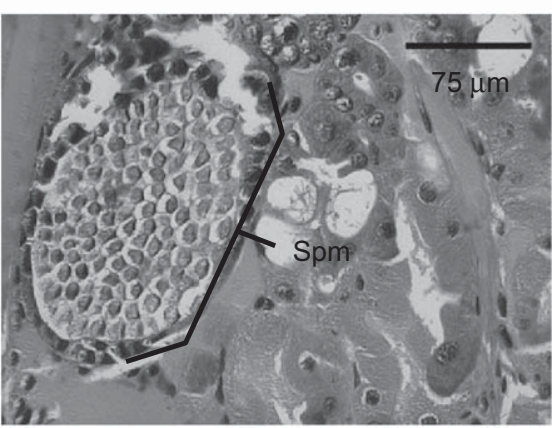

(F)

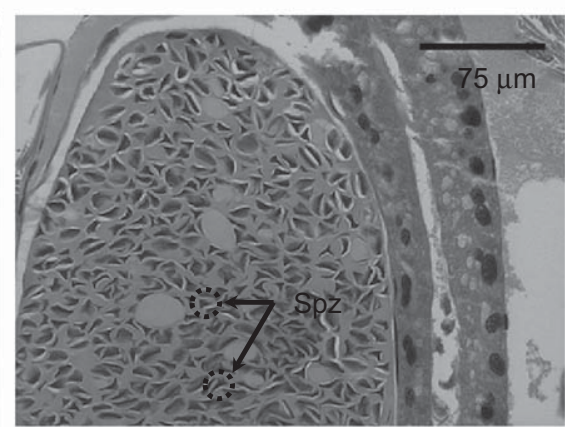

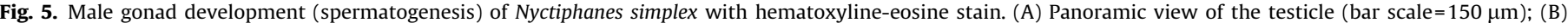

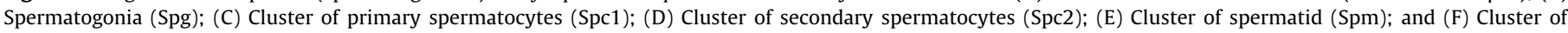
spermatozoa (Spz). $m=$ muscle. (B-F) Scale bars $=75 \mu \mathrm{m}$.

hatching time for $N$. simplex, as a nauplius, is relatively long (80-91 hours at $16^{\circ} \mathrm{C}$ ) and embryos leave the ovigerous sac as metanauplii between 92-140 h after spawning (Gómez-Gutiérrez and Robinson, 2005), which is a considerably longer IBP, compared with temperate broadcast-spawners (Feinberg et al., 2007). We estimated the $N$. simplex IBP using three distinct but complementary approaches:

(1) Observation of successive spawning events of females during onboard incubation. This is the most precise method, but its major limitation was the short length of the oceanographic cruises (usually $<20$ sampling days), effect of the food provided, and the effect of containment in a bottle. Only a few females spawned twice during the short cruises. However, this method provided strong evidence that the shortest possible IBP for this species was 7 days at $16{ }^{\circ} \mathrm{C}$ (GómezGutiérrez and Robinson, 2005).

(2) Proportion of gravid females (pink gonad) or ovigerous females within a population. Several of the IBPs estimated with this method were unrealistically short (1-5 days). It is impossible that a female could spawn again before the metanauplii leave the ovigerous sac. This suggests that ovigerous females were not homogeneously distributed horizontally or vertically (Figs. 2 and 4 in Gómez-Gutiérrez et al., 2010). In fact, Gendron (1992) reported that N. simplex in the Gulf of California commonly form reproductive daily surface swarms with a considerably large proportion of ovigerous females of the population (55-78\%), leading to a biologically impossible estimate of an IBP of 1.3-1.8 days using the inverse of these proportions, using the method described by Ross et al. (1982). However, in our study, this approach was useful, producing an average IBP of 10 days (using IBP between 6-26 days, $n=19$ stations), with a maximum IBP of 26 days, which is still shorter than the hypothetical average IBP assumed for $N$. australis (Hosie and Ritz, 1983) and N. simplex (Lavaniegos, 1995) of 30 days, suggesting that egg production rates in these studies were considerably underestimated by IBP and by the magnitude of the brood size (Gómez-Gutiérrez et al., 2010).

(3) Estimate of the proportion of females in a population whose gonads progressively mature as the embryos develop in the ovigerous sac. We developed this approach using the median embryonic development time as a biological clock to estimate 

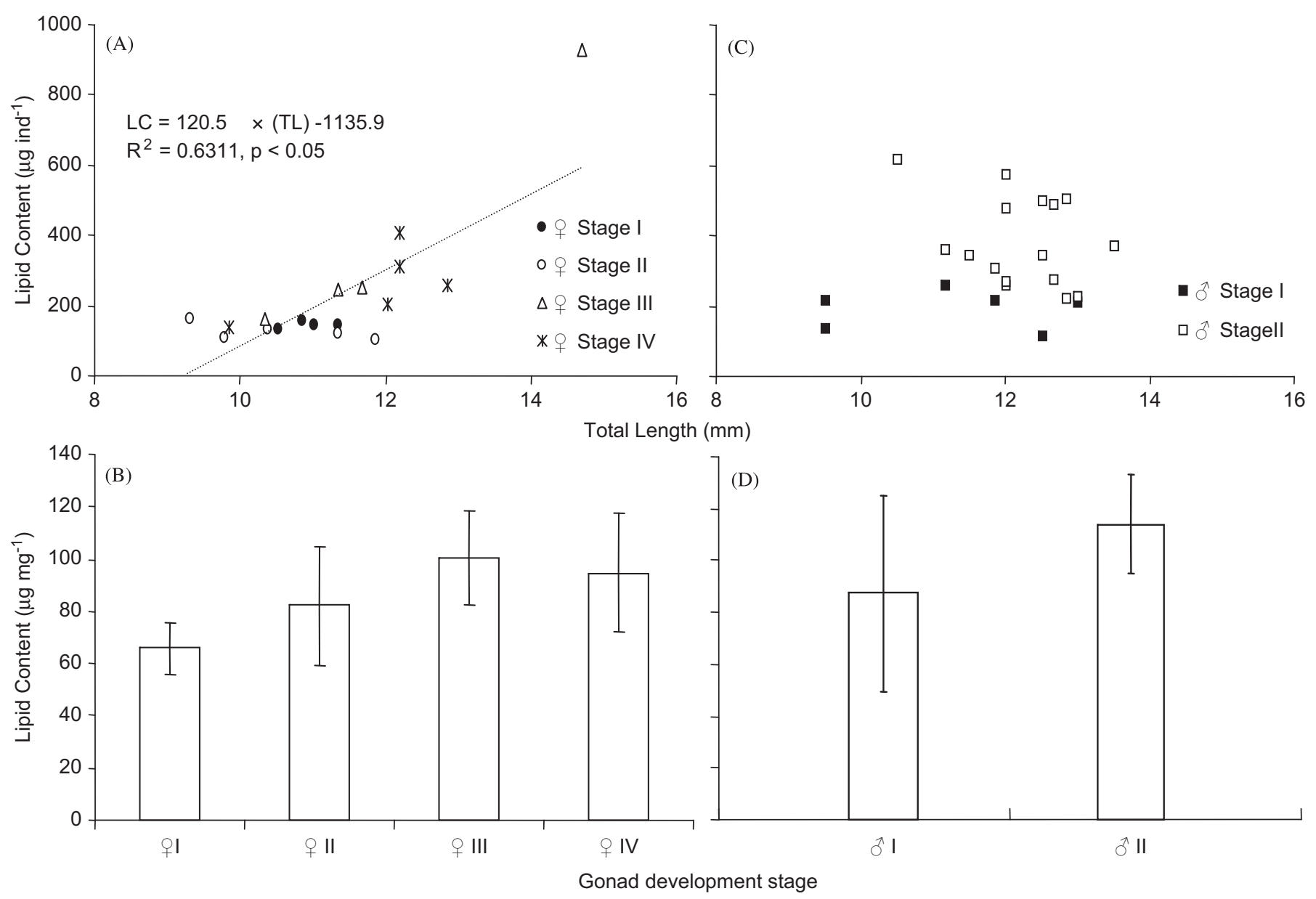

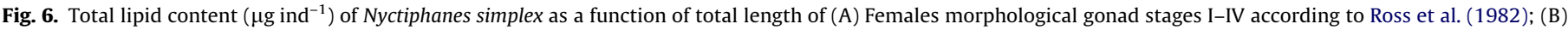

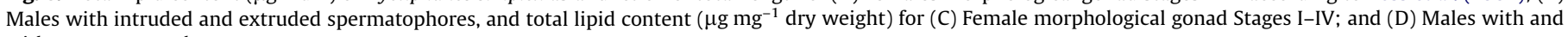
without spermatophore stages.

rates of gonadal development for successive stages. Although this approach cannot be used to estimate the average IBP, it was useful to estimate that $\sim 78 \%$ of ovigerous females with ,metanauplius embryos in their ovigerous sac are still in gonad developmental stage I or II. Therefore, it is likely that the IBP of a large proportion of the gravid population is considerably longer than 7 days (probably 9-15 days) and that only $\sim 22 \%$ of these females can spawn as soon as they release their metanauplius embryos (most likely $\sim 6-8$ days; considered highly productive females). These IBPs are relatively long compared with broadcast-spawners at 4-5 days in Euphausia pacifica (Feinberg et al., 2007; Pinchuk and Hopcroft, 2006). Tarling and Cuzin-Roudy (2003), using the proportion of gravid females in the population, proposed that the North Atlantic broadcast-spawning krill Meganyctiphanes norvegica have an IBP of 20-26 days (depending on temperature). Cuzin-Roudy et al. (1999) concluded that $M$. norvegica has one reproductive cycle for every two molt cycles, suggesting than tropical sac-spawners, counter intuitively, may have, in some cases, a shorter IBP that broadcastspawners and previously assumed for Nyctiphanes species (Lavaniegos, 1995; Hosie and Ritz, 1983). It is well know that spawning and molting processes usually do not occur at the same time because of the feedback function of gonad-stimulating hormone and ecdysteroid hormones. Precise synchronization of both processes is still in debate, particularly because several researchers had concluded that it is unlikely that spawning coincides with particular stages of the molt cycle, given the inconsistency in the spawning and molting relationship observed in long-term reared E. pacifica (Feinberg et al., 2007) or from direct observations of the interval between egg-laying and ecdysis of 60 Euphausia superba females reared on a research vessel (Nicol, 1989).

Considering an average brood size of 52 embryos female ${ }^{-1}$, an average IBP of 10 days (range: 7-26 days) and assuming an adult life span of 6 months; the average number of spawning events per female would be 18 (range: 26-7, respectively), and the average total fecundity of a female would be $\sim 940$ eggs female ${ }^{-1}$ life $\operatorname{span}^{-1}$ (360-1337 eggs female ${ }^{-1}$ life span $^{-1}$ ) (Gómez-Gutiérrez et al., 2010). This is the first time egg production rate is estimated using observed IBP for a sac-spawning species.

\subsection{Gonad development}

Ross and Quetin (2000) recently updated what is known about gonadal development and spawning strategies of euphausiids, mostly broadcast-spawners from temperate and polar latitudes. Nine species were intensely studied because they are targets of commercial fisheries. It is interesting that Ross and Quetin (2000) placed oogenesis in the early phase of gonad development 
(their Table 2). However, according to Yano (1988), oogenesis refers to the general gonadal development process. Thus, this early stage is the formation of the early nucleolus chromatin. We propose a modified classification of gonadal development for $N$. simplex (combining criteria proposed for decapods and broadcastspawners) that can be used for euphausiid's sac-spawners.

Gómez-Gutiérrez and Robinson (2005) erroneously proposed that $N$. simplex produce one batch of oocytes per gonadal cycle (total spawners) because they observed (with an stereoscope at $6.6 \times$ ) live, spawned ovigerous females or spent females with an 'empty' space in the cephalothorax, where the spent ovary is located. However, the histological evidence presented in our current study showed that $N$. simplex has, in fact, groupsynchronic ovaries because, when spawning leaves oocytes in previtellogenesis (Oc0-Oc3), they develop into three or four potential spawns. Other evidence of group-synchronic ovaries is that, independent of the gonadal development stage, there are always two or three different oocyte types at each phase. We concluded that $N$. simplex is a subtropical euphausiid with partial spawning reproduction behavior (group-synchronic ovaries). This is particularly interesting because $N$. simplex can mature in 5 days and, after molting, spawn in seven days after the earlier spawning event. The implication of this conclusion is that $N$. simplex has a larger reproductive potential than previously thought (Lavaniegos, 1995). Hosie and Ritz (1983) with N. australis and Stuart and Nicol (1986) and Barange and Stuart (1991) with Nyctiphanes capensis, Gómez-Gutiérrez (1995) with Nyctiphanes simplex, and Wilson et al. (2003) with Pseudeuphausia latifrons already have concluded that these sac-spawners have continuous maturation of the ovaries because more than one stage of ova in the ovaries examined (gonad-squashed slides). As the first formal histological study of gonads of sac-spawners, our findings indicate that, in terms of oocyte morphology, the oogenesis development of sac-spawners is very similar to broadcast-spawners. This supports findings of the highly conservative of the process of oogenesis in the family Euphausiacea (Kikuno and Kawamura, 1983; Cuzin-Roudy, 1987b, 1993, 1997a, 2000; Cuzin-Roudy and Amsler, 1991; Cuzin-Roudy and Buchholz, 1999) for Meganyctiphanes norvegica and Euphausia superba. We did not directly adopt classifications developed by Cuzin-Roudy (1993) and Cuzin-Roudy and Buchholz (1999) because Minagawa and Sano (1997), using transmission electron microscopy in their gonad classification based on the work of Yano (1988), developed a classification that seems to be more specific because it distinguished morphological differences between oil globule and yolk granules in decapods. Although we were not able to observe all of the substages of this gonad classification, using resinembedded gonads stained with black sudan, we observed that $N$. simplex oocytes Oc3 had small oil glubules in the ooplasm during early vitellogenesis (endogenous), which was not previously observed in other euphausiids (Cuzin-Roudy and Amsler, 1991; Cuzin-Roudy and Buchholz, 1999). Thus, we propose that these are precursor yolk of the lipidic type (oil globule) autosynthetized by the cell via endogenous vitellogenesis and not yolk per se (lipid droplet from exogenous origin). However, this must be corroborated in further biochemical studies to detect vitellogenin. This does not contradict the stages described by Ross et al. (1982) that takes into account that the ovary at Stage III is already developed and extending into the abdomen ('eggs are tightly packed and no longer transparent'). This feature has been related to lipid yolk accumulation (i.e. vitellogenesis) in the stage classification later devised for E. superba samples from the field (Cuzin-Roudy and Amsler, 1991). In terms of the number of spawns in a life span and length of reproductive season, species of both reproductive strategies have distinct gonad development: N. simplex (Lavaniegos, 1995; Gómez-Gutiérrez, 1995) and
N. australis (Hosie and Ritz, 1983) spawn throughout the year, while temperate and polar species spawn only at some seasons, but have longer life spans (Tarling and Cuzin-Roudy, 2003).

Although regression and rematuration of polar krill have been associated with photoperiod, temperature, and food availability as a lifespan strategy for species surviving several years (Kawaguchi et al., 2007b), oosorption of gonads in $N$. simplex females seem to be related with recent history of feeding and environmental conditions that are highly variable among individual females, since they were observed in virtually all oceanographic cruises during this study. $N$. simplex females with evidence of oosorption were more commonly observed in December 2004 in Bahía Magdalena and July 2007 in the Gulf of California, suggesting that the oosorption process, rather than spawning, may be highly sensitive to warmer conditions.

Our gonad histological information indicated that once a male $N$. simplex attains maturity, it continuously produces spermatozoa during its reproductive life to be always available for mature females. This is a particularly relevant adaptation since krill males apparently die younger than females (Kawaguchi et al., 2007a). We do not know if the spermatogenesis rate is reduced or stopped during the molting process or how long it takes a male to form intruded and extruded spermatophores. In fact, in all krill, it is not known how males transfer the spermatophore to the females, supposedly helped or stimulated by the male's petasm (Brinton, 1978; Pillar and Stuart, 1988). Another interesting discovery is that $N$. simplex has non-motile spermatozoa, aflagellated with triangle shape, indicating that fecundity strongly depends on male success to introduce the spermatophores correctly in the female thelycum. $N$. simplex have very conspicuous chromosomes during meiosis, a feature not commonly observed in other male crustaceans (Medina et al., 1998; Zavala-Hernández, 2007.

\subsection{Lipid metabolism during reproduction}

Virtue et al. (1995) reported that Nyctiphanes australis has 5-10\% lipid content (dry weight basis), but they did not study lipid changes during gonadal development. In this study, we found similar average lipid content for female $N$. simplex in previtellogenesis $(7 \pm 2 \%)$ and in vitellogenesis $(10 \pm 2 \%)$. Lipid content in $N$. simplex increases substantially from previtellogenesis (endogenous) to vitellogenesis (exogenous), but also significantly correlates with the size of the female. As females can mature in $<7$ days, it seems clear that size and maturation of the gonad are highly dependent on local food quality and concentration. Our results show that an immature female can increase its lipid content from 120 to $270 \mu \mathrm{g}$ during the vitellogenesis process. If carbon content of lipids represents $77.63 \%$ of its weight (Gnaiger, 1983a, b), a female would increase from 92 to $215 \mu \mathrm{g}$ carbon. This means that increases in carbon content vary between $4.1 \%$ and $13.8 \%$ of dry weight (average $8.34 \%$ ), that is, virtually the same average percentage that was calculated for females with the reproductive effort method $(8.4 \%$, range $0.9-27.9 \%$ ) (Gómez-Gutiérrez et al., 2010), which suggests a negligible carbon content change between the later oocytes substages and the fertilized eggs, in this case multiple cells.

Independent of total length, males with intruded spermatophores contains less relative lipid content $(8 \pm 4 \%)$ than males with extruded spermatophores $(11 \pm 2 \%)$. These observations, along with histological observations of the spermatogenesis process, suggest that male spermatogenesis is a continuous process that is relatively expensive for males. The increase of carbon content of intruded and extruded spematophores accounts for $5.4 \%$ of their dry weight. This value might seem relatively high 
in comparison with females (averaged 8\%). However, this is more complicated because females can develop from the previtellogenesis to vitellogenesis stage in as little as 1 day (direct observations), whereas the time between males spermatophores that are intruded and extruded is unknown. Virtue et al. (1996) detected a significant decrease in the lipid reserve in E. superba males after reproduction, an indicator of the relatively high energy cost involved in the fertilization process.

\subsection{Conceptual comparison of sac-spawning and broadcast- spawning reproductive strategies}

Our multi-disciplinary study allowed us to use $N$. simplex as a species model to compare the reproductive strategies of sacspawners with the relatively better known reproductive strategy of broadcast-spawners. This comparison used available information about three broadcast-spawners (E. pacifica, T. spinifera, and T. inermis) in the northern California Current System and Gulf of Alaska (Feinberg et al., 2007; Gómez-Gutiérrez, 2002, 2003a, b; Pinchuk and Hopcroft, 2006) (Table 3) and complementary information about $M$. norvegica from the North Atlantic (Tarling and Cuzin-Roudy, 2003) and Euphausia superba from the Antarctic Ocean (Kawaguchi et al., 2007b). As far as is known, broadcastspawners have blue (Euphausia pacifica, E. eximia, E. distinguenda), green-blue (Thysanoessa spinifera), or gray (E. superba) gonads when they are gravid, although some do not seem to have a colored gonad (Thysanoessa inspinata). Sac-spawners, like N. simplex (Gómez-Gutiérrez and Robinson, 2005) and N. difficilis (Gómez-Gutiérrez, 2003a,b), usually have a pale, pink-colored gonad when they become gravid, suggesting that different carotene pigments are associated with gonad maturation that may differ at the biochemical level. Although this suggests that reproductive strategies may be considerably distinct, our histological evidence shows that morphology and evolution of the female gonad is remarkably similar in both types of reproduction. These differences are more related to female behavior and reproductive rates, such as IBP, proportion of the gonad spawned, and egg production.

Temperate broadcast spawners can be characterized as having asynchronic ovaries (partial spawners) because they usually spawn at short IBPs (2-8 days, but as long as 79 days), with brood size and IBP highly variable within and among individuals (poorly correlated to female size; TL explains $<14 \%$ of the variability of brood size) from one spawning to the next, according to highly specific individual metabolism (even when food quality and concentration are monitored under controlled incubations) (Feinberg et al., 2007; Gómez-Gutiérrez, 2003a; Gómez-Gutiérrez et al., 2007; Pinchuk and Hopcroft, 2006). However, $M$. norvegica seems to have highly synchronized spawning and molting process with production of an egg pulse (IBP) every 20 to 26 days (Tarling and Cuzin-Roudy, 2003). A female can maintain a colored gonad in the mature stage for long periods of spawning; with relatively short, but variable IBP (Feinberg et al., 2007). The molting process seems not to be highly synchronized with spawning events in broadcast-spawners (Feinberg et al., 2007; Nicol, 1989; Nicol et al., 1995) occasionally molting on the same day as spawning, but more frequently occurring after spawning. Tarling and Cuzin-Roudy (2003) found in field observations that $M$. norvegica spawned during late intermolt and early premolt, but never coinciding with the actual molt. We have frequently observed in E. pacifica and $T$. spinifera have several molts between spawns. However, intense egg-producing periods may affect intermolt period. Recently, Feinberg et al. (2007) tested whether females shrink as a response to the high energy demand for egg production. The average weight (\%) that a female devotes to reproduction (reproductive effort) is usually $9 \%$, but can be as high as $45 \%$ (Feinberg et al., 2007; Gómez-Gutiérrez et al., 2007). Brood size is highly variable among females and, even in the same female's spawning life, E. pacifica spawn, on average, 150 eggs in one spawn, but could be as high as 800 eggs per event (Feinberg et al., 2007; GómezGutiérrez, 2003a). E. superba can produce brood sizes of $\sim 5000$ eggs female ${ }^{-1}$, but the brood size is highly variable among individuals (Nicol et al., 1995). Hatching success of broadcastspawners range from nearly 0 to $100 \%$, but this is highly variable among females and even in the same female in successive spawns, since sibling embryos may use distinct hatching mechanisms (Gómez-Gutiérrez, 2002), and free-sinking eggs are heavily consumed by zooplankton, such as the polychaete (Tomopteris), ctenophores, amphipods (Phronimia), and zooplanktophagous filtering animals, and sometimes infected by parasitoid dinoflagellates (Gómez-Gutiérrez, pers. observations). Broadcast spawning is a trade-off between large volumes of eggs and high mortality of embryos in the column water. Eggs of broadcastspawners have very high variability in perivitelline space, with just-spawned eggs having no visible perivitelline space. The space increases through embryonic development to sizes that are probably related to environmental conditions. The space is significantly larger in areas with stress conditions (Timofeev,

Table 3

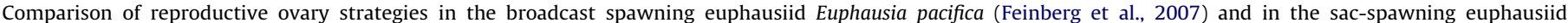
Nyctiphanes simplex, based on histological and incubation observations in this study.

\begin{tabular}{|c|c|c|}
\hline \multirow[t]{2}{*}{ Biological feature } & \multicolumn{2}{|l|}{ Reproductive strategy } \\
\hline & Broadcast-spawners & Sac-spawners \\
\hline Female gonad coloration (gravid) & Purple, blue-green, gray* or colorless & Pink \\
\hline Ovary & Asynchronous ovaries (partial spawning) & Group-synchronous ovaries (partial spawning) \\
\hline \multirow[t]{2}{*}{ Interbrood period (IBP) } & Highly variable within and among females & Comparatively less variable within females \\
\hline & Regional average $2-8$ days (maximum $=79$ days) & Regional average 10 days (maximum $=26$ days) \\
\hline \multirow[t]{2}{*}{ Brood size (BS) } & Poorly associated with female total length & Significantly linearly associated with female total length \\
\hline & Average 150 eggs fem ${ }^{-1}\left(\max =800\right.$ eggs fem $\left.^{-1}\right)$ & Average 52 eggs fem ${ }^{-1}\left(\max =116\right.$ eggs $\left.\mathrm{fem}^{-1}\right)$ \\
\hline \multirow[t]{2}{*}{ Reproductive effort (\%) } & Highly variable within and among females & Relatively less variable within and among females \\
\hline & Average $9-15 \%(\max =45 \%)$ & Average $8 \%(\max =28 \%)$ \\
\hline Perivitelline space (PVS) & $\begin{array}{l}\text { Usually large and highly variable among individual embryos } \\
\text { and as a function of environmental conditions }\end{array}$ & $\begin{array}{l}\text { Usually very small and without variability as a function of } \\
\text { environmental conditions }\end{array}$ \\
\hline Molting and spawning & $\begin{array}{l}\text { Poorly synchronized, but several studies consider it highly } \\
\text { synchronized }\end{array}$ & Assumed relatively more synchronized \\
\hline
\end{tabular}

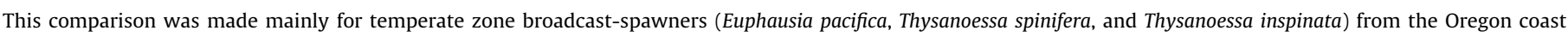

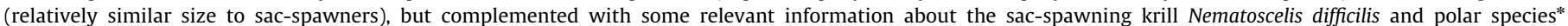
(Euphausia superba and Meganyctiphanes norvegica) that are significantly larger that sac-spawners. 
2000; Timofeev and Sklyar, 2001; Timofeev et al., 2004). Sibling embryos of broadcast-spawners usually have highly variable development and hatching time (Gómez-Gutiérrez, 2002, 2003a), as well as distinct rates of larval development (Table 3).

Reproduction in $N$. simplex, as a hypothetical model to represent sac-spawners, seems to have group-synchronic ovaries with partial spawning per ovary cycle. This species spawns at relatively longer average IBPs and brood sizes are better associated with female size compared with broadcast-spawners. Successive spawns tend to be proportional to the female weight (8\%) because larger females can accommodate larger ovigerous sacs containing more embryos. This implies a relatively more discrete partitioning of energy of reproduction than broadcastspawners because a female cannot develop another batch of eggs until she releases her current brood at the metanauplius stage and because an ovigerous female have never been seen with a pink gonad (gravid) simultaneously. The molting process in sacspawners seems to be more synchronized with spawning events compared to broadcast-spawners, and this relatively longer time for reproductive effort probably does not affect female growth to the same degree as in broadcast-spawners, since no shrinking process was detected in females that spawned twice under laboratory conditions. However, body shrinkage occurred over longer periods. We observed one female that spawned and molted simultaneously, but this affected her swimming activity for several hours, a disadvantage that may explain why this is a very rare behavior in nature. Range of brood size in sac-spawners is relatively small and average weight of a female that is devoted to reproduction is $8.4 \%$, with a maximum of $27.9 \%$ (lipid approach). This is, on average, similar to the average of $9 \%$, but almost half of the maximum $45.1 \%$ recorded for some 'overachieving' broadcast spawning E. pacifica (Feinberg et al., 2007; Gómez-Gutiérrez et al., 2007). Hatching success of sac-spawners is usually less variable than in broadcast-spawners (usually $>40 \%$ ) in $N$. difficilis (Gómez-Gutiérrez, 2003b) and almost always 100\% in N. simplex and has less variability in hatching mechanisms within a species (Gómez-Gutiérrez and Robinson, 2005; Gómez-Gutiérrez, 2006). Mortality of embryos depends on the ability of the mother to avoid predators; thus, survival of the brood goes from total loss or almost total recruitment of a female's progeny. Death during embryonic development (parasitism) usually involves all of a brood size rather than specific siblings, as occurs in broadcastspawners, but these are infrequently observed events. Sac-spawners make the trade-off between producing moderatesized broods and relatively low egg mortality. Eggs of sac-spawners usually have small (Nemoto et al., 1972; Gómez-Gutiérrez et al., 2003b) or absent perivitelline space (Gómez-Gutiérrez and Robinson, 2005) to maximize yolk volume and space in the ovigerous sac for incubating many embryos. Females with unusually large brood sizes ( $>116$ embryos) in the metanauplius stage, usually a darker ovigerous sac, seems to have difficulty swimming and this may affect their ability to avoid predators. Like broadcast-spawners, sibling larvae of sac-spawners have very high variability in their rate of larval development (Lavaniegos, 1992; Gómez-Gutiérrez, 2003b), indicating distinctive individually fitness of embryos of the same females, which makes them highly flexible to variable environmental conditions from a population perspective (Table 3 ).

\section{Conclusions}

$N$. simplex has group-synchronic ovaries with a partial spawning strategy because it has four distinct oocytes substages (only three simultaneously) at each stage of gonadal development, probably able to spawn 4 or 5 times per gonadal cycle. Females have the ability to reabsorb the gonad in $<4$ days when food conditions are unfavorable and/or when exposed to high temperatures. Each female have a very variable resting phase, but once oogenesis restarts, females can develop the gonad from earlier oogenesis to vitellogenesis in $<3$ days at $16{ }^{\circ} \mathrm{C}$. We concluded that females invest comparatively larger proportion of their body weight $(8.3 \%)$ to gonadal development, based on lipid content, and egg production, using the reproductive effort method (see Gómez-Gutiérrez et al., 2010) than previously thought (Lavaniegos, 1995). This is relatively close, contrary to expected, to other similar-sized temperate broadcast-spawners, on average $\sim 9 \%$ (Feinberg et al., 2007). It appear that larger total fecundity of broadcast-spawners, compared to sac-spawners is related to larger broods and shorter IBPs, rather than greater reproductive effort, defined as \% of weight each female devotes each spawning event. Also, sac-spawners have considerably higher hatching success compared to broadcast-spawners and the mean IBP of $\sim 10$ days is only about twice the time as broadcast-spawners with $\sim 4-5$ days. Larval recruitment among sac-spawners is large enough, perhaps the same magnitude, as broadcast-spawners and this explains why, in some eutrophic ecosystems, sac-spawners outnumber broadcast-spawners. $N$. simplex males continuously invest energy, after first maturation, about $5.4 \%$ of their dry weight in the spermatogenesis process to produce spermatophores, which may represent a significantly greater energy cost to reproduction. This finding is contrary to the previous assumption that male spermatogenesis is insignificant in energy expenditure in euphausiids.

\section{Acknowledgments}

We thank Eulalia Meza at CIBNOR for technical assistance in histology, Karmina Arroyo-Ramirez for technical assistance with the DEPBAMA biological data, and Ira Fogel at CIBNOR for editorial clarification. We also thank the crew of the R/V 'El Puma,' graduate students and researchers at the Fisheries Ecology Laboratory of ICMyL-UNAM, UABCS, and CICIMAR for their assistance with acoustical and zooplankton sampling. J.G.G. and C.J.R. were supported by S.N.I. fellowships and J.G.G. by grants from COFAA-IPN and EDI-IPN. This project was funded by grants from Centro Interdisciplinario de Ciencias Marinas-Instituto Politécnico Nacional, CONACYT-FOSEMARNAT, CONACYT-SAGAR$\mathrm{PA}$, and Instituto de Ciencias del Mar y Limnología at the Universidad Nacional Autónoma de México. We thank to the three referees for made cleaver critics that significantly improved the content of this manuscript.

\section{References}

Barange, M., Stuart, V., 1991. Distribution patterns, abundance and population dynamics of the euphausiids Nyctiphanes capensis and Euphausia hanseni in the northern Benguela Upwelling System. Marine Biology 109, 93-101.

Block, D.S., Bejarano, A.C., Chandler, G.T., 2003. Ecdysteroid concentrations through various life-stages of the meiobenthic harpacticoid copepod, Amphiascus tenuiremis and the benthic estuarine amphipod, Leptocheirus plumulosus. General and Comparative Endocrinology 132, 151-160.

Brinton, E., 1978. Observations of spermatophores attached to pleopods of preserved male euphausiids. Crustaceana 35, 241-249.

Brinton, E., Townsend, A.W., 1980. Euphausiids in the Gulf of California-the 1957 cruises. California Cooperative Oceanic Fishery Investigation Report 21, 211-236.

Brinton, E., Ohman, M.D., Townsend, A.W., Knight, M.D., Bridgeman, A.L., 2000. In: Euphausiids of the World Ocean. Expert Center for Taxonomic Identification, Amsterdam.

Christie, W.W., 2003. In: Lipid Analysis: Isolation, Separation, Identification and Structural Analysis of Lipids. The Oily Press, Bridgwater, UK.

Cornew, S., Stuart, V., Beckley, L.E., 1992. Population structure, biomass and distribution of Nyctiphanes capensis (Euphausiacea) in the vicinity of Algoa Bay, South Africa. South Africa Journal of Zoology 27, 14-20. 
Cuzin-Roudy, J., 1987a. Gonad history of the Antarctic krill Eupahusia superba Dana during its breeding season. Polar Biology 7, 237-244.

Cuzin-Roudy, J., 1987b. Sexual differentiation in the Antarctic krill Euphausia superba Dana (Crustacea: Euphasiacea). Journal of Crustacean Biology 7 518-524.

Cuzin-Roudy, J., 1993. Reproductive strategies of the Mediterranean krill, Meganyctiphanes norvegica and Antarctic krill, Euphausia superba (Crustacea: Euphausiacea). Invertebrate Reproductive Development 23, 105-114.

Cuzin-Roudy, J., 2000. Seasonal reproduction, multiple spawning, and fecundity in northern krill, Meganyctiphanes norvegica, and Antarctic krill, Euphausia superba. Proceedings of the Second International Symposium on Krill. Canadian Journal of Fisheries and Aquatic Science 57, 6-15.

Cuzin-Roudy, J., Amsler, M.O., 1991. Ovarian development and sexual maturity staging in Antarctic krill, Euphausia superba Dana (Euphausiacea). Journal of Crustacean Biology 11, 236-249.

Cuzin-Roudy, J., Buchholz, F. 1999. Ovarian development and spawning in relation to the moult cycle in Northern krill, Meganyctiphanes norvegica (Crustacea: Euphausiacea), along a climatic gradient. Marine Biology 133, 267-281.

Cuzin-Roudy, J., Albessard, E., Virtue, P., Mayzaud, P., 1999. The scheduling of spawning with the moult cycle of Northern krill (Crustacea: Euphausiacea): A strategy for allocating lipids to reproduction. Invertebrate Reproduction and Development 36 (163-170).

De Silva-Dávila, R., Palomares-García, R., 1998. Unusual larval growth production of Nyctiphanes simplex. Bahía de La Paz, Baja California, México. Journal of Crustacean Biology 18, 490-498.

De Silva-Dávila, R., Palomares-García, R., Martínez-López, A., Carballido-Carranza, A., 2002. Standing stock of Nyctiphanes simplex in the southern region of the California Current System. Journal of Plankton Research 24 1057-1066.

Färber-Lorda, J., Lavín, M.F., Zapatero, M.A., Robles, J.M., 2004. Effects of wind forcing on the trophic conditions, zooplankton biomass and krill biochemical composition in the Gulf of Tehuantepec. Deep-Sea Research II 51, 601-614.

Feinberg, L.R., Shaw, C.T., Peterson, W.T., 2007. Long-term laboratory observations of Euphausia pacifica fecundity: a comparison of two geographic regions. Marine Ecology Progress Series 341, 141-152.

Folch, J., Lees, M., Sloane Stanley, G.H., 1957. A simple method for the isolation and purification of total lipids from animal tissues. Journal of Biological Chemistry 226, 497-509.

Gnaiger, E., 1983a. Calculations of the energetic and biochemical equivalence of respiratory oxygen consumption. In: Gnaiger, E., Forstner, H. (Eds.), Polarographic oxygen sensors. Aquatic and physiological applications. Springer Berlin, pp. 337-345.

Gnaiger, E., 1983b. Microcalorimetric monitoring of biological activities. Ecological and toxicological studies in aquatic animals. Science Tools 30, 21-26.

Gendron, D.L., 1992. Population structure of daytime surface swarms of Nyctiphanes simplex (Crustacea: Euphausiacea) in the Gulf of California, Mexico. Marine Ecology Progress Series 87, 1-6.

Gómez-Gutiérrez, J., 1995. Distribution patterns, abundance and population dynamics of the euphausiids Nyctiphanes simplex and Euphausia eximia in the west coast of Baja California, Mexico. Marine Ecology Progress Series 119 63-76.

Gómez-Gutiérrez, J., 1996. Ecology of early larval development of Nyctiphanes simplex Hansen (Euphausiacea) off the southwest coast of Baja California, México. Bulletin of Marine Sciences 58, 131-146.

Gómez-Gutiérrez, J., 2002. Hatching mechanism and delayed hatching of the eggs of three broadcast euphausiid species under laboratory conditions. Journal of Plankton Research 24, 1265-1276.

Gómez-Gutiérrez, J., 2003a. Comparative Study of the Population Dynamic Secondary Productivity, and Reproductive Ecology of the Euphausiids Euphausia pacifica and Thysanoessa spinifera in the Oregon Upwelling Region. Ph.D. Thesis, Oregon State University, Corvallis, USA.

Gómez-Gutiérrez, J., 2003b. Hatching mechanism and accelerated hatching of the eggs of a sac-spawning euphausiid Nematoscelis difficilis. Journal of Plankton Research 25, 1397-1411.

Gómez-Gutiérrez, J., 2006. Hatching mechanisms and death of euphausiid embryos during hatching: evidences for evolutionary reversal of the freeliving nauplius? Océanides 21, 63-79.

Gómez-Gutiérrez, J., Robinson, C.J., 2005. Embryonic, early larval development time, hatching mechanism and interbrood period of the sac-spawning euphausiid Nyctiphanes simplex Hansen. Journal of Plankton Research 27, 279-295.

Gómez-Gutiérrez, J., De Silva-Dávila, R., Lavaniegos, E.B., 1996. Growth production of the euphausiid Nyctiphanes simplex at the coastal shelf off Magdalen Bay, Baja California Sur, México. Marine Ecology Progress Series 138 309-314

Gómez-Gutiérrez, J., Feinberg, L.R., Shaw, C.T., Peterson, W.T., 2007. Interannual and geographical variability of the brood size of the euphausiids Euphausia pacifica and Thysanoessa spinifera along the Oregon coast (1999-2004). DeepSea Research I 54, 2145-2169, doi:10.1016/j.dsr.2007.09.003.

Gómez-Gutiérrez, J., Tremblay, N., Martínez-Gómez, S., Robinson, C.J., Del ÁngelRodríguez, J., Rodríguez-Jaramillo, C., Zavala-Hernández, C., 2010. Biology of the subtropical sac-spawning euphausiid Nyctiphanes simplex along the northwestern coast of Mexico: Vertical and horizontal distribution patterns. Deep-Sea Research II 57 (7-8), 606-615.
Haywood, G.J., Burns, C.W., 2003. Feeding response of Nyctiphanes australis (Euphausiacea) to various nanoplankton sizes and taxa. Marine Ecology Progress Series 253, 209-216.

Hosie, G.W., Ritz, D.A., 1983. Contribution of moulting and eggs to secondary production in Nyctiphanes australis (Crustacea: Euphausiacea). Marine Biology 77, 215-220.

Howard, D., Smith, C., 1983. Histological techniques for marine bivalve mollusks. NOAA Technical Memorandum NMFS-F/NEC, 25-97.

Humason, G.L., 1979. In: Animal Tissue Techniques. W.H. Freeman, San Francisco. Karnovsky, M.J., 1965. A formaldehyde-glutaraldehyde fixative of high osmolality for use in electron microscopy. Journal of Cell Biology 27, 137-138.

Kawaguchi, S., Finley, L.A., Jarman, S., Candy, S.G., Ross, R.M., Quetin, L.B., Siegel, V., Trivelpiece, W., Naganobu, M., Nicol, S., 2007a. Male krill grow fast and die young. Marine Ecology Progress Series 345, 199-210.

Kawaguchi, S., Yoshida, T., Finley, L., Cramp, P., Nicol, S., 2007b. The krill maturity cycle: a conceptual model of the seasonal cycle in Antarctic krill. Polar Biology 30, 689-698, doi:10.1007/s00300-006-0226-2.

Kikuno, T., Kawamura, A., 1983. Observations of the ovarian eggs and spawning habits in Euphausia superba Dana. Memorial National Institute Polar Research, Special Issue 27, 104-121.

Lavaniegos, B.E., 1992. Growth and larval development of Nyctiphanes simplex in laboratory conditions. California Cooperative Oceanic Fishery Investigation Report 33, 162-171.

Lavaniegos, B.E., 1995. Production of the euphausiid Nyctiphanes simplex in Vizcaíno Bay, western Baja California. Journal of Crustacean Biology 15, 444-453.

LeRoux, A., 1973. Observations sur le development larvaire de Nyctiphanes couchii (Crustacea:Euphausiacea) au laboratoire. Marine Biology 22, 159-166.

Marsh, J.B., Weinstein, D.B., 1966. A simple charring method for determination of lipids. Journal of Lipid Research 7, 574-576.

Mauchline, J., 1968. Development of eggs in the ovaries of euphausiids, and estimation of fecundity. Crustaceana 14, 155-163.

Mauchline, J., 1980. The biology of mysids and euphausiids. In: Blaxter, J.H.S., Russell, FS, Younge, M. (Eds.), Advances of Marine Biology, Vol. 18. Academic Press, London, pp. 1-681.

Mauchline, J., Fisher, L.R., 1969. The biology of the euphausiids. In: Russell, F.S., Yonge, M. (Eds.), Advances in Marine Biology, 7. Academic Press, London, pp. $1-454$

Mayzaud, P., Albessard, E., Cuzin-Roudy, J., 1998. Changes in lipid composition of the Antarctic krill Euphausia superba in the Indian sector of the Antarctic Ocean: influence of geographical location, sexual maturity stage and distribution among organs. Marine Ecology Progress Series 173, 149-162.

Medina, A., Vila, Y., Santos, A., 1998. The sperm morphology of the euphausiid Meganyctiphanes norvegica (Crustacea, Eucarida). Invertebrate Reproduction and Development 34, 65-68.

Minagawa, M., Sano, M., 1997. Oogenesis and ovarian development cycle of the spiny lobster Panulirus japonicus (Decapoda:Palinuridae). Marine Freshwater Research 48, 875-887.

Nemoto, T., Kamada, K., Hara, K., 1972. Fecundity of a euphausiid crustacean, Nematoscelis difficilis, in the North Pacific Ocean. Marine Biology 14, 41-47.

Nicol, S., 1989. Apparent independence of the spawning and molting cycles in female Antarctic krill (Euphausia superba) Dana. Polar Biology 9, 371-375.

Nicol, S., De La Mare, W.K., Stolp, M., 1995. The energetic cost of egg production in Antarctic krill (Euphausia superba Dana). Antarctic Science 7, 25-30.

Pilditch, C.A., McClatchie, S., 1994. Quantitative analysis of carnivory in the krill Nyctiphanes australis, with an examination of the effect of non-preferred phytoplankton alternative prey. Marine Ecology Progress Series 107, 41-54.

Pillar, S., 1984. Laboratory studies on the larval growth and development of Nyctiphanes capensis (Euphausiacea). Journal of Plankton Research 7, 223-240.

Pillar, S., Stuart, V., 1988. Population structure, reproductive biology and maintenance of Euphausia lucens in the Southern Benguela Current. Journal of Plankton Research 10, 1083-1098.

Pillar, S., Stuart, V., Barange, M., Gibbons, M.J., 1992. Community structure and trophic ecology of euphausiids in the Benguela ecosystem. South African Journal of Marine Science 12, 393-409.

Pinchuk, A.I., Hopcroft, R.R., 2006. Egg production and early development of Thysanoessa inermis and Euphausia pacifica (Crustacea: Euphausiacea) in the northern Gulf of Alaska. Journal of Experimental Marine Biology and Ecology $332,206-215$.

Ponomareva, L.A., 1969. Investigations on some tropical euphausiid species of the Indian Ocean. Marine Biology 3, 81-86.

Ritz, D.A., Hosie, G.W., 1982. Production of the euphausiid Nyctiphanes australis. Storm Bay, Southeastern Tasmania. Marine Biology 68, 103-108.

Ritz, D.A., Hosie, G.W., Kirkwood, R.J., 1990. Diet of Nyctiphanes australis Sars (Crustacea: Euphausiacea). Australian Journal of Marine and Freshwater Research 41, 365-374.

Ross, R.M., Quetin, L.B., 1982. Euphausia superba: fecundity and physiological ecology of its eggs and larvae. Antarctic Journal of the United States 17, 166-167.

Ross, M., Quetin, L.B., 1983. Spawning frequency and fecundity of the Antarctic krill Euphausia superba. Marine Biology 77, 201-205.

Ross, R.M., Quetin, L.B., 2000. Reproduction in Euphausiacea. In: Everson, I. (Ed.), Krill Biology, Ecology and Fisheries. Fisheries and Aquatic Resource Series. Blackwell Science, Cornwall, UK, pp. 150-181.

Ross, R.M., Daly, K.L., English, T.S., 1982. Reproductive cycle and fecundity of Euphausia pacifica in Puget Sound, Washington. Limnology and Oceanography 27, 304-314. 
Saout, C., Quéré, C., Donval, A., Paulet, M., Samain, F., 1999. An experimental study of the combined effects of temperature and photoperiod on reproductive physiology of Pecten maximus from the Bay of Brest. Aquaculture 172, 301-314.

Sheenan, D., Hrapchak, B., 1973. In: Theory and Practice of Histotechnology. Mosby, London.

Stuart, V., 1992. Fecundity of Euphausia lucens (Hansen) - laboratory evidence for multiple broods. Journal of Experimental Marine Biology and Ecology 160, 221-228.

Stuart, V., Nicol, S., 1986. The reproductive potential of three euphausiid species from the southern Benguela region. Journal of Experimental Marine Biology and Ecology 103, 267-274.

Tarling, G.A., Cuzin-Roudy, J., 2003. Synchronization in the molting and spawning activity of northern krill (Meganyctiphanes norvegica) and its effect on recruitment. Limnology and Oceanography 48, 2020-2033.

Timofeev, S.F., 2000. Discovery of eggs and larvae of Thysanoessa raschii (M. Sars, 1846) (Euphausiacea) in the Laptev Sea: Proof of euphausiids spawning on the shelf of the Arctic Ocean. Crustaceana 73, 1089-1094.

Timofeev, S.F., Sklyar, V.V., 2001. Egg size in the euphausiid Thysanoessa raschii (M. Sars, 1864) (Euphausiacea) in the Barents Sea. Crustaceana 74, 1201-1211.

Timofeev, S.F., Sklyar, V.V., Savinov, M.V., 2004. Stabilizing selection on egg size in the euphausiid, Thysanoessa raschii (M. Sars, 1864) (Euphausiacea) in the Barents Sea. Crustaceana 77, 267-275.
Tolivia, J., Navarro, A., Tolivia, D., 1994. Polychromatic staining of epoxy semi-thin sections: a new and simple method. Histochemistry 101, 51-55.

Virtue, P., Johannes, R.E., Nichols, P.D., Young, J.W., 1995. Biochemical composition of Nyctiphanes australis and its possible use as an aquaculture feed source: lipids, pigments and fluoride content. Marine Biology 122, 121-128.

Virtue, P. Nichols, P., Nicol, S., Hosie, G., 1996. Reproductive trade-off in male Antarctic krill, Euphausia superba. Marine Biology 126, 521-527.

Wallace, R.A., Selman, K., 1981. Cellular and dynamic aspects of oocyte growth in teleosts. American Zoologist 21, 325-343.

Wilson, S.G., Meekan, M.G., Carleton, J.H., Stewart, T.C., Knott, B., 2003. Distribution, abundance and reproductive biology of Pseudeuphausia latifrons and other euphausiids on the southern North West shelf, Western Australia. Marine Biology 142, 369-379.

Yano, I., 1988. Oocyte development in the kuruma prawn Penaeus japonicus. Marine Biology 99, 547-553.

Zavala-Hernández, C. 2007. Estrategias reproductivas en tres especies de eufáusidos (Crustácea: Euphausiacea) subtropicales en el Golfo de California. Licenciatura Thesis. Universidad Autónoma de Baja California Sur, La Paz, B.C.S., Mexico. 